\title{
SURFACE EROSION AND DISTURBANCE AT ARCHEOLOGICAL SITES: IMPLICATIONS FOR SITE PRESERVATION
}

\author{
by \\ Anne MacDonald \\ Environmental Laboratory \\ DEPARTMENT OF THE ARMY \\ Waterways Experiment Station, Corps of Engineers \\ 3909 Halls Ferry Road, Vicksburg, Mississippi 39180-6199

\section{US-CE-CProperty of the United States Government}
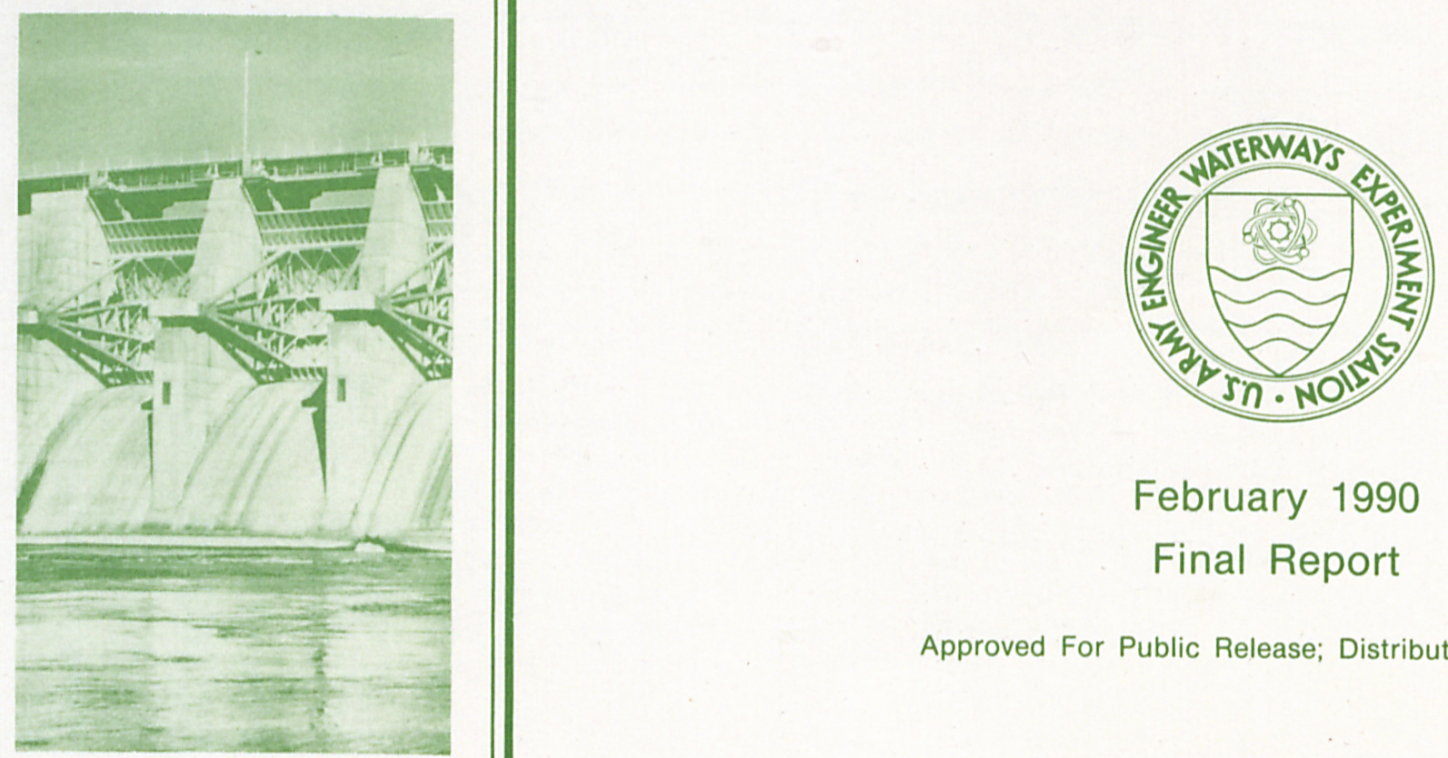

February 1990

Final Report

Approved For Public Release; Distribution Unlimited

FESEARCH LIBRARY
US ARMY ENGINEER WATERWAYS
EXPERIMENT STATION
VICKSBURG, MISSISSIPPI

Prepared for DEPARTMENT OF THE ARMY US Army Corps of Engineers Washington, DC 20314-1000 Under EIRP Work Unit 32357 
Unclassified

SECURITY CLASSIFICATION OF THIS PAGE

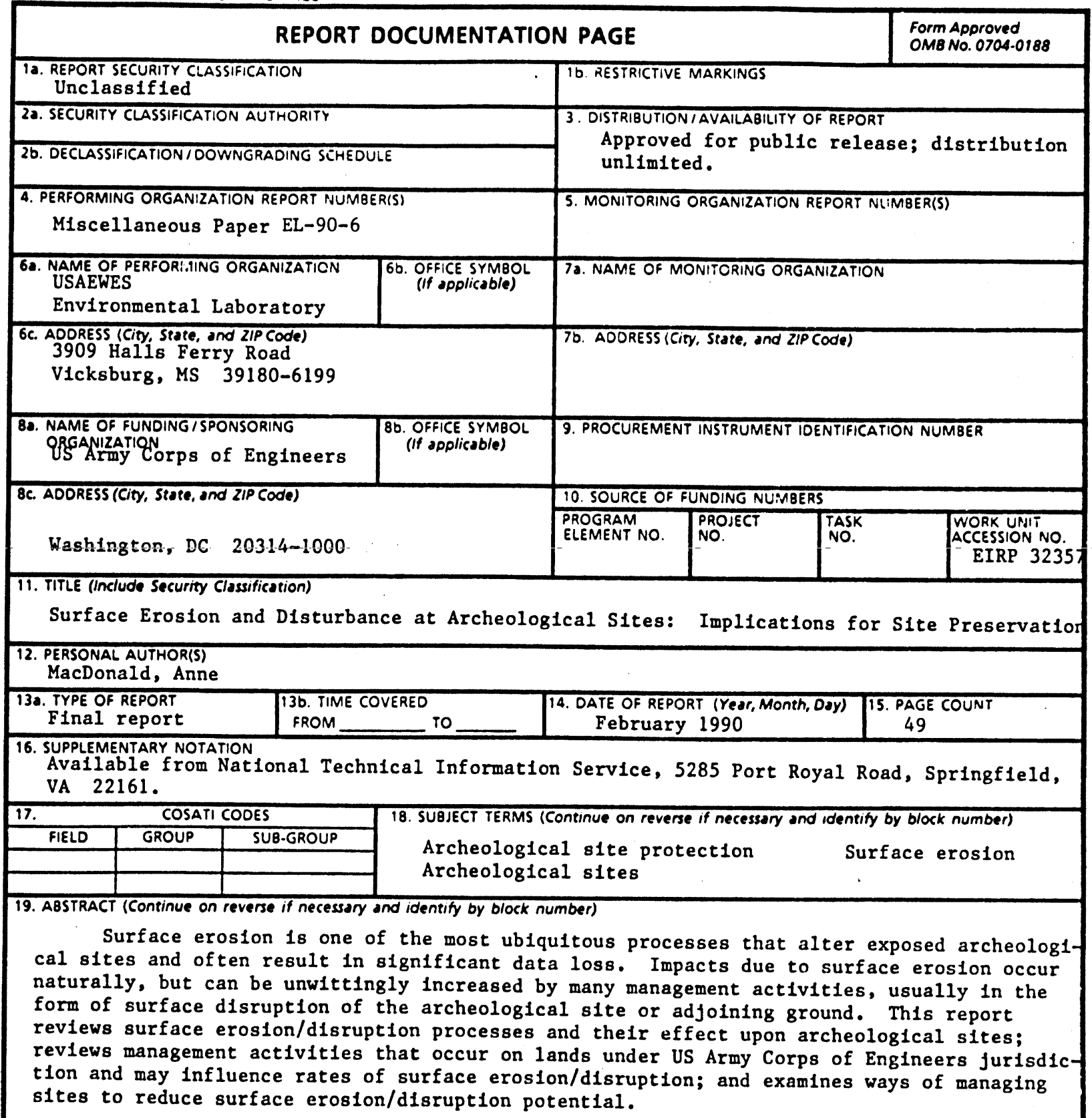

\begin{tabular}{|c|c|c|c|}
\hline $\begin{array}{l}20 \text { DISTRIBUTION/AVAILABILITY OF ABSTRACT } \\
\text { UUNCLASSIFIEDNNLIMITED } \square \text { SAME AS RPT. }\end{array}$ & $\square$ OTIC USERS & $\begin{array}{l}\text { 21. ABSTRACT SECURITY CLASSIFICAT } \\
\text { Unclassif led }\end{array}$ & TION \\
\hline 22.. NAME OF RESPONSIBLE INDIVIOUAL & & 22b. TELEF-1ONE (Include Aredi' ' de) & 22C. OFFICE SYMBOL \\
\hline
\end{tabular}




\section{PREFACE}

This paper was written as part of Work Unit 32357, "Field Preservation of Cultural Sites," of the Environmental Impact Restarch Program (EIRP). The EIRP is sponsored by Headquarters, US Army Corps of Engineers (HQUSACE), and is assigned to the Environmental Laboratory (EL) of the US Army Engineer Waterways Experiment Station (WES). Technical Monftors are Dr. Jchn Bushman, Mr. David P. Buelow, and Mr. Dave Mathis of HQUSACE.

This review of applicable literature was performed by Ms. Anne MacDonald, Water Resources Engineering Group (WREG), Environmental Engineering Division (EED), EL, under the technica]. direction of Dr. James J. Hester of the Department of Anthropology, University of Colorado, while on an Intergovernmental Personnel Act assignment to WES. This work was conducted under the direct supervision of Drs. F. Douglas Shlelds and Paul R. Schroeder, Acting Chiefs, WREG, and Dr. John J. Ingram, Chief, WREG. General supervision was provided by Dr. Raymond L. Montgomery, Chlef, EED and Dr. John Harrison, Chief, EL. Dr. Roger T. Saucier, EL, is the EIRP Program Manager. Technical reviewers were Dr. Paul R. N1ckens and Mr. David L. Ford.

Commander and Director of WES during preparation of this report was COL Larry B. Fulton, EN. The Technical Director was Dr. Robert W. Whalin.

This report should be cited as follows:

MacDonald, Anne. 1990. "Surface Erosion and Disturbance at Archeological Sites: Implications for Site Preservation," Miscellaneous Paper EL-90-6 , US Army Engineer Waterways Experiment Station, Vicksburg, MS. 


\section{CONTENTS}

PREFACE............................................. 1

CONVERSION FACTORS, NON-SI TO SI (METRIC) UNITS OF MEASUREMENT......... 3

PART I $\quad$ INTRODUCIION ................................ 4

PART II: NATURAL SURFACE DISRUPTION PROCESSES AFFECTING ARCHEOLOGICAL SITES ..................................... 6

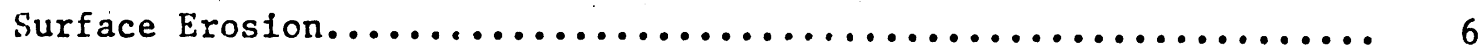

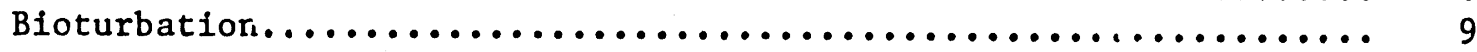

PART III: SURFACE DISTURBANCE OF ARCHEOLOGICAL STTES JN THE CONTEXT

OF HUMAN LAND USE............................. 11

Construction................................... 1]

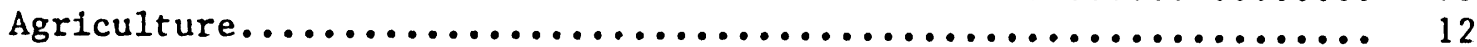

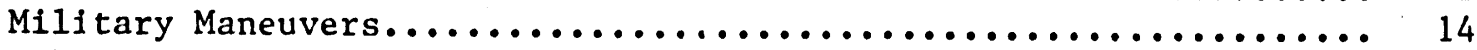

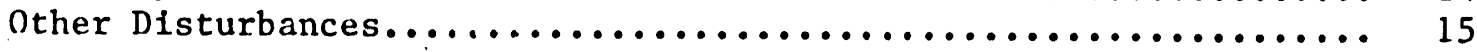

PART IV: PREDICTING ONSITE SOIL EROSION..................... 18

Application of the USLE........................... 18

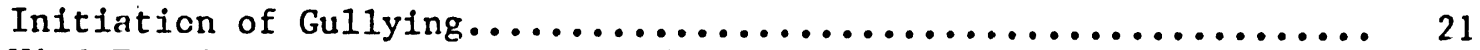

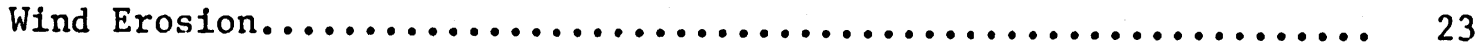

PART V: MANAGEMENT OF SURFACE EROSION AT ARCHEOLOGICAL SITES FOR SITE PRESERVATION PURPCSES......................... 26

Management Goals.................................. 26

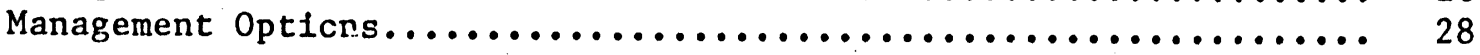

REFERENCES ......................................... 30

TABLES $1-7$

FIGURES 1-9 


\section{CONVERSION FACTORS, NON-SI TO SI (METRIC) \\ UNITS OF MEASUREMENT}

\begin{tabular}{|c|c|c|}
\hline Multiply & By & To Obtain \\
\hline acres & $4,046.873$ & square metres \\
\hline feet & 0.3048 & metres \\
\hline Inches & 25.4 & millimetres \\
\hline pounds (mass) & 0.4535924 & kilograms \\
\hline square miles & 2.589998 & square kilometres \\
\hline tons $(2,000$ pounds, mass $)$ & 907.1847 & kflograms \\
\hline
\end{tabular}


SURFACE EROSION AND DISTURBANCE AT ARCHEOLOGICAL SITES:

IMPLICATIONS FOK SITE PRESERVATION

PART I: INTRODUCTION

1. Among all the processes that alter exposed archeological sites, surface erosion is one of the most ubiquitous and commonly recognized by archeologists working in site preservation (Thorne, Fay, and Hester 1987). It has acted upon sites even prior to abandonment and has continued to modify many sites to the present day. Yet, the magnitude of this alteration is so variable that an individual site may be. In pristine condition at the present (because of minimal erosion and/or burial) or may no longer exist as an entity recognizable to trained archeologists due to high erosion rates.

2. At least three fundamental archeological activities require an understanding of erosional processes. The first activity is site identification during surveys. The second is surface collection of artifacts, by which decisions as to the excavation potential, functional/cultural context, -and or management of a site are made (Redman 1987, Schlanger and Orcutt 1986, Nickens and Chandler 1987). The third activity is excavation; data results from excavation may be impossible to interpret without an understanding of these "transforms" (Schiffer 1983). Understanding site modification resulting from past surface erosion is left to the interpretation of the archeologist.

3. Many archeologists are involved in cultural resources management in which they may make decisions to actively preserve or excavate a site. This stewardship role extends to cases where the site may be subjected to diffuse facility operations and maintenance activities even in the absence of archeological activity. A site may even be in passive preservation--not protected per se, but not in immediate danger of disturbance as the result of human activity. Under these conditions, erosion can still be severe enough to result in significant data loss (Figure 1). Unfortunately, many management activities currently undertaken on US Army Corps of Engineers (CE) lands and projects containing archeological sites can unwittingly exacerbate surface erosion on sites, resulting in a loss of archeological data. These potentially destructive activities usually stem from some surface disruption of the site or adjoining ground. 
4. The purposes of this report are to: (a) review surface erosion/ disruption processes and their effect upon archeological sites, (b) review management activities that occur on lands under $\mathrm{CE}$ jurisdiction and influence rates of surface erosion/disruption, and (c) examine ways of managing sites to reduce surface erosion/disruption potential. A major aspect of site management is determining the magnitude of surface erosion at a site. To this end, methods of determining absolute or relative soil loss from sheetwash, gully erosion, and wind erosion are summarized in this report. Methods of data aquisition required to make erosion estimates are revlewed as well. Information on these methods will allow the archeologist to collect relevant data during site visits or supervise the data collection efforts by others.

5. The following discussion of active surficial processes applies to any plot of land, regardless of its concentration of recognized archeological remains; therefore, the idea of what constitutes a "site" will not be debated. Furthermore, while it is recognized that prehistoric and protohistoric man was quite capable of altering his environment (In such a way as to rearrange the loci of artifacts and features from contemporaneous or earlier culturcs, in addition to actual land sculpturing), these activities are not subject to. present day control and will not be explicitly discussed. Finally, the methods outlined in this report are not suitable for reconstructing long-term erosion rates. The fleld of geomorphology provides a large body of literature on landscape reconstruction. 
PART II: NATURAL SURFACE DISRUPTION PROCESSES AFFECTING ARCHEOLOGICAL SITES

6. Two significant surface disturbance processes, surface erosion and bioturbation, may act on a site. The magnitude of these process effects depends upon site conditions from the time of initial occupation to the present.: As the sophistication of archeological data recovery has grown to include the reconstruction of past lifeways and their paleoecological framework, it has become more important for archeologists to understand and account for disturbance processes in site formation (e.g., Wood and Johnson 1978, Schiffer 1983). These processes may rearrange artifacts both vertically and horizontally, may concentrate or dilute artifact assemblages, and may thoroughly disrupt features. Stratigraphic rearrangement of paleoecological or archaeometric data may also occur by these processes.

7. The review conducted for this study shows the lack of data on the erodibility of cultural soils. The literature search revealed no comparative studies of erodibility of cultural solls and surrounding "natural" soils. For this reason, throughout this report, cultural soils are considered to be high in organic matter and more disturbed (1.e., bioturbated) than surrounding solls. This combination favors solls that are friable to loose in consistency and granular in texture (Brady 1984). Obvious exceptions include hard-packed floors, a compacted area beneath major upright structural support, or a rubble building foundation.

\section{Surface Erosion}

8. Falling rain may land on vegetation (termed interception) or the ground surface and may rest in elther location unt1l it evaporates, filters into the soil (perhaps to emerge at the surface downslope), or flows downslope under the influence of gravity. It is this last process, water flowing over the ground surface, which is most responsible for the loss of soll on a site, including the degradation of structures. The flowing water can exert sufficient shear stress on soll particles to dislodge and transport them downslope. This shear stress is directly proportional to the water depth and the slope of the ground. The shear stress is counteracted by forces inherent in the soil surface that resist erosion. Therefore, the interaction of many variables 
related to site conditions determines the rate of surface erosion at that location.

Typical erosion patterns and their implications

9. Patterns of erosion processes can be illustrated by runoff generation in two cases: a site with deciduous forest cover and a site in semiarid scrublands. Both have identical topography, contain similar parent material for the soil, and are subject to rainstorms of similar intensity.*

10. Deciduous forest cover. Surface erosion under natural forest cover is generally minimal. First, much rainfall can be intercepted by the vegetative canopy and can remain there until it evaporates. Also, the kinetic energy of a raindrop (responsible for dislodging soil particles) can be dissipated as it falls through vegetation. Those drops that reach the ground can encounter a litter layer, which further detains water. Roots add cohesion to the soll while promoting drainage. Soll that is loose and rich in organic matter built up over millenia can easily soak up rain (i.e., it possesses a high infiltration capacity) and allow it to be transmitted either downslope or vertically into the ground water (indicating high soil permeability). Because of this pattern of rapid infiltration in forest soils, gradual creep of the soll mantle downslope under the force of gravity, rather than surface erosion, is the primary agent by which soll is delivered to stream channels in forested environments. Only at the base of slopes or in swales does shallow ground water return to the surface (surface overland flow after Dunne (1970)); at that point, it is capable of eroding soil over a wider area. Most commonly, water emerging from the subsurface quickly exceeds a critical depth and becomes channelized. As the threshold of channelized flow in permanent drainages is crossed, erosion processes and magnitudes change; this threshold limits the scope of this report.

11. Semiarid scrublands. Under semiarid conditions, vegetation is sparse while rainfall is plentiful enough to generate signfficant runoff several times a year. Erosion is greater in this situation for two reasons. First, there is less Interception. More rainfall reaches the ground directly, with higher kinetic energy per drop; this results in a greater likelihood of

* References such as Water in Environmental Planning (Dunne and Leopold 1978) may be consulted for a more thorough discussion of these processes. 
soil particles being dislodged and transported downslope. Second, the soil has less organic matter in the upper layers and therefore a lower infiltration capacity (Wischmeier and Mannering 1965). Pore spaces in the soil fill quickly with rainwater; once these are filled, additional rain runs off. Because of irregularities in the microtopography of the ground surface, this runoff quickly forms small channels, termed rills (Emmett 1978; Schumm, Harvey, and Watson 1984). Rills are characterized by their small size (usually $<5 \mathrm{~cm}$ wide by 1 to $2 \mathrm{~cm}$ deep), their instability, and the parallelism of their beds with the ground slope on which they form. They are usually less intricately branched than the more permanent drainage systems into which they drain. In the interim, their formation can lead to considerable erosion of the hillside on which they form. This erosion can be measured in centimetres of lowering of the ground per storm on a moderately sloped (10-percent gradient) surface if a maximum drainage density of $\sim 70 \mathrm{~m}$ of rill per square metre of surface is reached (Schumm, Harvey, and Watson 1984). In addition, soil loosened by rainsplash on steep slopes ( $>25$ percent) and not stabilized by vegetation is also subject to erosion by dry ravel (dry soll fall of discrete grains, aggregates, or larger particles).

Effects of surface erosion on archeological site formation

12. Surface erosion is a major archeological site altering process. It operates at a magnitude which is a function of time since human occupation, vegetation cover, and ground surface slope. Fortunately, humans are (geologically) recent Immigrants to North America, living and working on locally flat land wherever possible. Where this is not the case and sites are found on sloping ground, signiflcant effort must be made to allow for translocation of artifacts in the colluvial environment,* following techniques such as those in Nelson, Plooster, and Ford (1987) or Marron (1985). Thompson and Bettis (1983), working in an actively evolving landscape in loess-covered western Iowa, found that

the archeological record was affected like other surficial sediments by eplsodic erosion and alluviation throughout the Holocene. These effects were systematic, orderly, and can be reconstructed. It remains to fill in details of alluvial stratigraphies in western Iowa and elsewhere and then to improve methods of detecting and investigating the archeological record. 
13. The true effect of surface erosion on archeological resources may be seen when a dearth of recognized sites occurs in an area that should have been inhabited in the past. This scarcity can occur because sites have been either eroded away entirely or they may be buried by sediments eroded from somewhere else. Because surface erosion processes operate on any active landscape, surface erosion reduction is a significant component of any archeological site preservation program.

\section{Bloturbation}

14. Bioturbation of the upper soil horizons, whether by root penetration (floralturbation), animal burrowing, or reworking by invertebrates (worms, insects, crawfish, etc.) (both classed as faunalturbation), is another means by which cultural strata are disrupted. (Ste Wood and Johnson (1978) for a thorough review.) Although most extensive in the upper metre of the soil profile, bloturbation by organisms that must be in contact with the water table or capillary fringe (crawfish, phreatophytic plants, and large oaks, for example) has been observed to depths of tens of metres** (Wood and Johnson 1978). In these cases, local minimum elevation of the water table will control the maximum extent of bioturbation. Generally, bloturbation loosens the soll while preserving soll aggregates, resulting in soil that is therefore more porous and less erodible than surrounding undisturbed soil. Exceptions do occur, however. Tree roots may increase local soil desiccation and lead to locally harder soil (which may itself be erosion resistant), and extensive rodent tunneling can lead to soil piping and gullying precisely because the soil is more loosely packed in the burrows than in the surrounding soil.

15. Most burrowing animals and insects bring finer soil fractions to the surface, concentrating coarser particles (rocks, artifacts) at depth (Moeyersons 1978, Wood and Johnson 1978, Bocek 1986). This process may obliterate hard-packed occupation surfaces and other features and cause artifacts to be rearranged in the vertical dimension. If bioturbation is not extensive,

* On or at the base of hillslopes, characterized by mixed deposits of hillslope soils and bedrock in various states of weathering, with possible local incorporation of alluvium.

** Personal Communication, 10 April 1988, Imogene Blatz, Geobotanist, San Jose State University, San Jose, CA. 
the remains (krotovina) can be recognized and accounted for in archeological interpretation. Often, however, burrowing organisms can turn over the upper 1 to $2 \mathrm{~m}$ of soil in a matter of decades. The precise rate and depth of faunalturbation will depend upon the specie(s) involved and local environmental factors such as the depth to the water table, impenetrable strata, or bedrock.

16. Plant root tips exploit existing volds in the soll and then enlarge radially. Therefore, while they crosscut features, they likely have minimal effect on the displacement of artifacts unless the plant is uprooted. When this happens, soil and other objects attached to the roots are both vertically and laterally displaced. Forest geomorphologists have recognized for a number of years that uprooted trees are a significant cause of soll erosion in forested environments (Hack and Goodlett 1960, Dietrich and Dunne 1978). The deeper the root system, the less 11kely a plant is to be uprooted. For this reason, better preservation of archeological stratigraphy in forested (or formerly forested) environments is indicated when root casts from deeply rooted trees are found, rather than when there is no evidence of their presence due to frequent uprooting of trees. 
PART III: SURFACE DISTURBANCE OF ARCHEOLOGICAL SITES IN THE CONTEXT OF HUMAN LAND USE

17. Humans, like plants and animals, have always had a role in the evolution of the landscape. Since the rise of agriculture, that role has increased significantly because of the nature of ground (and drainage) disturbance and the population concentrations characteristic of agricultural societies (Goudie 1982). Today, mountains can be moved, and, in many cases, the consequences of doing so can be determined. In fact, much of the understanding of the landscape evolution process has come from trying to unravel the effects of human disturbance on the landscape, such as construction, tilling, ranching, logging, and mining (Wolman and Schick 1967; Patton and Schumm 1975; Trimble 1975; Womack and Schumm 1977; Swanson et al. 1982; Marron 1987). 18. Human disturbances of the surface of the Earth have resulted in the loss of information about man's historic and prehistoric existence. In one of the more complete inventories of site loss, an estimated 75 to 80 percent of all known sites in eastern Arkansas were seriously damaged or destroyed prior to 1972 from agricultural practices alone; this loss was prior to the mid1970's agricultural boom in the midwest (Ford and Rolingson 1972, Medford 1972). Given that the replication of patterns and results is as important in archeology as it is in any other science, site loss and/or disturbance (particularly that which is preventable) represents an exhaustion of a nonrenewable resource and is a serfous threat to the discipline.

19. In the following sections, the effects of activities on $C E$ lands or projects which disturb the land surface and may damage shallow archeological sites are discussed.

\section{Construction}

20. Construction activities are generally recognized as destructive of archeological sites, primarily because of the amount or areal extent of earth that is commonly moved. For this reason, Federal laws require assessment of the effects of major construction projects on cultural resources (Reservoir Salvage Act of 1960, as amended) and management of sites prior to construction on Federal lands (National Historic Preservation Act of 1966, as amended). For sites listed or eligible to be listed on the National Register of Historic 
Places (NRHP), the Federal government provides funds for the mitigation of impacts on the site (Holt 1987). Significant sites that cannot be avoided by destructive activities are ideally excavated to the fullest extent possible. However, construction commonly leaves ground bare and subject to surface erosion at some time in the process which may in turn lead to impacts over a wider area than just the construction site. Wolman and Schick (1967), for example, noted a tripling of the sediment yield of a Maryland watershed as agricultural land was developed for urban uses; the sediment yield decreased below the agricultural level once the basin was fully urbanized. Erosion control measures are now generally required on construction projects to eliminate offsite impacts of accelerated erosion.

\section{Agriculture}

21. Agricultural activities constitute a second significant disturbance to the land surface occurring locally on land for which the $C E$ bears some responsibility. Tillage occurs on CE lands leased to, or rights-of-way owned by, farmers; in addition, planting of grain or similar crops to enhance wildlife habitat may also require plowing. Under similar conditions of slope and rainfall intensity, a tilled field will erode more rapidly than an untilled one because of disturbance of the vegetation. The agricultural community sees topsoil as a renewable resource; this is recognized in the sol1-1oss tolerance factors published by the Soll Conservation Service in county soil surveys. The implication is that for agricultural purposes, soil may be lost from a fleld at a rate of 2 to 5 tons*/acre/year without a loss of crop production as the result of weathering and soll formation lower down in the profile. Unfortunately for farmers, soll loss (particularly loess-covered regions of the upper Midwest, Mississippi River Valley, and the Palouse of eastern Washington) can exceed 10 tons/acre/year. Unfortunately for archeologists, each ton of soll lost per acre per year represents an average lowering of the ground surface by $0.15 \mathrm{~mm}$; 10 tons of soll lost per year over a 100-year period results in $150 \mathrm{~mm}$ of average lowerlng of the ground surface. Some areas, particularly near the crown of hills as well as in alluvial valleys,

* A table of factors for converting non-SI units of measurement to SI (metric) units is presented on page 3. 
can be more prone to erosion than other locations. Thomas Jefferson observed a conical mound near Charlottesville that was reduced in height $5.5 \mathrm{ft}$ (46 percent) after 12 years of plowing (Wishy and Leuchtenburg 1977). Finally, sediment lost from uplands is avallable to bury sites farther down in the drainage. Hence, the probability of active landscapes altering site visibility and protection (see Thompson and Bettis (1983)) is exacerbated under agricultural conditions.

22. Given the amount of soil commonly moved around in agricultural fields, it should not be surprising that known archeological sites are disturbed if not destroyed in these settings. Tilling the soil disrupts anywhere from the top $\sim 0.25 \mathrm{~m}$ during annual plowing to 0.5 to $0.75-\mathrm{m}$ depths during the deep plowing designed to break a subsurface hardpan (plowpan) resulting from repeated shallow plowing. Such plowing is responsible for artifact breakage, disruption of surface context and archeological features, and artifact dispersion, particularly in the horizontal dimension. In addition, fields are commonly leveled to promote even drainage, ease of herbicide application (necessary when using no-till methods of soll preparation), and general ease of tilling. They may be contoured or terraced to conserve soil. (Ironically, such soll conservation measures applied to agricultural or range sites may damage cultural resources if the ground surface is disrupted. Integrated rather than single purpose land management efforts are necessary to prevent this damage.)

23. Because so many areas of the country have been tilled, considerable effort has been made recently to determine what effect repeated plowing has on archeological sites. This research has taken two approaches. First, beginning with extant sites which have been plowed, detailed artifact recovery has been employed and used to test the hypothesis that some sort of archeologically reasonable pattern wili emerge from density contours of artifacts. An example of this approach is the study by McManamon (1984), who excavated the plowzone (rather than simply surface collecting $1 \mathrm{t}$ ) using a small ( 1 by $1 \mathrm{~m}$ ) grid and 1/4-in. screen to recover artifacts. The study concluded that "core" loc1 of artifacts left from discrete activities in a site could still be found, although artifacts were (presumably) dispersed horizontally away from this core. Features were likely to be truncated or obliterated if they were in the plowzone, suggesting that feature destruction is the most serious consequence of plowing. McManamon (1984) also noted a superficial resemblance 
between organic rich topsoil above a plowpan and a buried occupational surface.

24. A second line of investigation, exemplified by the work of Odell and Cowan (1987), examines the movement of surrogate artifacts placed in a known pattern on the surface and then observed after repeated plowing. Odell. and Cowan (1987) found that plowing caused exhumation of shallowly buried 1ithic "artifacts" and that larger pleces were preferentially collected by surface survey. Average cumulative displacement of "artifacts" after 12 plowings was 1 to $2 \mathrm{~m}$, usually paralle 1 to the furrow pattern rather than perpendicular to it. No correlation was found between the absolute distance displaced and "artifact" size. Most importantly, they found that their site size approximately doubled after 14 plowings (although they do not volce an opinion about this being a maximum probable dispersal). Systematically placed "artifacts" became apparently clustered by the end of the experiment when the surface collection data were analyzed. Clearly, such studies raise more questions, but they do point towards a possible understanding of a tillage transform function for archeological sites.

\section{Military Maneuvers}

25. Disturbance of the ground surface by military vehicles on US Army Installations is another means by which archeological sites can be damaged. No data are avallable tc predict actual soil displaced by these activities, although scars left from World War II tank training exercises are st111 visible in the highly arid environment of the Mojave Desert. A survey of training impacts on archeological sites was undertaken in 1983 at Fort Hood, TX (Carlson and Briuer 1986), showing that site condition had deteriorated at 10 to 30 percent of the sites in the west Fort Hood training area per year after training intensity was increased. The variation in this percentage is due to the use of a number of disturbance indices and evaluation bias between those making the initial and those making the posttraining estimates of site condition. In addition, the degree of disturbance was difficult to estimate based upon pretraining and posttraining information and did not correlate well. with training intensity. Of the 23 sites determined to be in worse condition after training by at least one disturbance measure, 15 were protected by wire, 
brush, signs, or burial; the other 8 sites were unprotected except by a general request made of military personnel to avoid sites.

\section{Other Disturbances}

26. Construction, tilling, and military training are the most visible anthropogenic activities likely to result in surface erosion or disturbance of archeological sites on CE and US Army managed lands. However, other operations and maintenance activities (discussed in the following paragraphs) also have the potential to change the surface erosion regime of an archeological site.

Chaining

27. Chaining, the practice of dragging a heavy chain between two bulldozers over the ground surface, is used to remove large shrubs and trees from large tracts of land, often to alter vegetation from shrublands to grasslands. Commonly used in the 1950's and 1960's in the southwestern United States to convert pinon-juniper woodlands to grasslands suitable for grazing, it is less common today on public lands due in part to its destructiveness toward archeological resources (Thorne, Fay, and Hester 1987). Soil (and any archeological features contained therein) is disturbed when trunks are vigorously shaken prior to breaking or when the shrub or tree is uprooted; sites are also disturbed when overrun by heavy equipment from loading and soll surface disturbance. Equipment turnarounds are particularly destructive, as in chaining when soil is wet and equipment treads can sink in. Chaining in a downslope (rather than contour) direction can result in the concentration of surface runoff in the bulldozer tracks, enhancing the formation of gullies in the process. Finally, areas compacted by heavy equipment usually take longer to revegetate.

Grazing

28. Grazing can have two effects on surface and shallow archeological sites. First, hooves of large animals can break artifacts at or very near the ground surface (Wandsnider 1987). Trampling can also cause some displacement in both the horizontal and vertical direction depending upon the characteristics of the soil. Second, grazing animals can leave a site more prone to surface erosion by reducing the vegetative cover, compacting the soil, and 
forming paths or, in the extreme, terracettes on slopes. These may, in turn, concentrate surface runoff and intercept shallow ground water (Higgins 1979). Mowing

29. Mowing activities can disturb archeological sites in much the same way as grazing. Large mowing machines are heavy enough to compact the soil over time, which can alter or destroy archeological features. In addition, mowers can relocate or break artifacts near the surface. Both of these actions result in deterioration or loss of site integrity. Mowing also reduces the vegetation cover, though it usually is not done so often that surface erosion is increased significantly.

Recreation

30. Recreation on CE lands is usually tightly controlled and waterbased, dominated by boating facilities and associated camping. Where trails are present, their continued use by people or off-road vehicles (ORV's) can, however, disrupt the land surface enough to accelerate erosion and potentially damage nearby archeological sites. Shoreline and streambank areas, exposed already to erosion processes of greater magnitude than overland flow, seem particularly vulnerable to the impacts of foot traffic. Trails should be designed so that runoff is kept in natural channels whenever possible or dispersed broadly over the landscape using waterbars or similar structures, and the trail surface should be pervious to eliminate runoff. (Impervious surfaces, such as asphalt, require more runoff management.) obviously, any diverted runoff should not impinge directly upon an archeological site. Finally, recreation may open archeological sites up to increased risk of vandalism by increasing access to or traffic near a site. Timbering

31. There are three primary activities associated with timber harvesting and replanting which have the potential to create surface disturbance and erosion at archeological sites. The first of these is the construction of access roads to the harvest areas. Usually, these access roads are temporary in nature and of limited width. Next is the yarding or bringing of the logs to the road itself. This process can range from severe to minimal disturbance to the grounil surface, depending on the method employed. Tractor (bulldozer) or skidder yarding drags the logs along the ground using heavy equipment and is most disruptive; skid trails from this procedure can range up to a metre in depth and can disrupt drainage enough to eventually become gullies themselves. 
Cable yarding can efther drag the $10 \mathrm{~g}$ along the ground or fully suspend the log (skyline yarding), with less ground disturbance. The last major activity is postharvest site preparation for planting which may consist of land reclamation, piling up the slash and burning it onsite, and planting activities. 
32. The processes of runoff generation and the entrainment of soil particles can vary tremendously in space and time because of heterogeneities in soil and vegetation and because of the intensity, duration, and patterns of rainfall events. Yet these processes are desirable for many reasons, such as soll conservation in agriculture and nonpoint source pollution control, to be able to predict rates of soil erosion. To date, all methods for predicting soil erosion have been empirical. That is, they depend upon a combination of actual site data and independently derived coristants. While these models may not be theoretically rigorous, the best of them are designed to be broadly applicable and used by a wide variety of land managers; this makes them useful to archeologists or technicians under the supervision of archeologists.

33. The most powerful ton.1 to date for predicting onsite soil erosion is the Universal Soll Loss Equation (USLE) (Wischmeier and Smith 1978). The USLE was developed in the years following World War II by the Agricultural Research Service for the purpose of assigning priorities to agricultural soil conservation projects and has been modified and broadened to aid in predicting soil loss from many natural and disturbed landscapes. Because the equation was developed for use on relatively small areas and because the necessary data can be estimated from existing soil surveys, aerial photography, and large scale topographic maps of the area of interest, it should be very useful to archeologists in estimating soil erosion at individual archeological sites in the context of project operations and maintenance.

\section{Application of the USLE}

34. The USLE combines effects from the erosion processes enumerated in Part II of this report in the following form:

$$
A=\text { RKI.SCP }
$$

where

$$
A=\text { computed soll loss per unit area (units of } K \text { and } R \text { ) }
$$


$R$ = rainfall and runoff factor, an index of annual rainfall amount, duration, frequency, and intensity ( $p$ lus snowmelt and/or applied water factor where apropos) (Figure 2). Seasonality of rainfall must be related to stage in ground disturbance (e.g., plowingplanting-growing-harvesting schedules or construction schedules) and included in the calculation of local " $C$ " value if necessary.

$\mathrm{K}=$ soll erodibility factor, or soll loss per rainfall erosion index units on a unit plot $72.6 \mathrm{ft}$ long, 9-percent slope, and clean tilled (Figure 3). (Values are published for each soll series in county soil surveys dated after mid-1970's, or available from local soil Conservation Service or Agricultural Stabilization and Conservation Service.)

$L=$ slope-length factor (LS), or ratio of soil loss from slope of given length to soll loss on unit plot (Figure 4). (Measured as the effective slope length in feet from the upslope origin of overland flow to the plot of interest, limited in the downslope direction by either deposition or the beginning of a well-defined channel.)

$S=$ slope-steepness factor, or ratio of soll loss from slope of given gradient to soil loss on unit plot, where gradient is given in percent slope (Figure 4)

$C=$ cover and management factor, or ratio of soll loss from area of specified cover and management relative to similar area in tilled continuous fallow (Tables 1,2 , and 3 and Figures 5 through 8 )

$\mathrm{P}=$ support practice factor, or ratio of soll loss from area of specified support practice (e.g., terracing, strip-cropping) to similar area with straight row farming straight up and down the slope (Tables 4, 5, and 6).

35. The value of each of the coefficients is obtained by applying site specific data to the nomographs and Tables 1-6, interpolating when necessary. For Instance, the $\mathrm{K}$ value is obtained from a textural and grain-size analysis of the soil at the site. Typical $K$ values for the natural soils surrounding an archeological site are published in the local soll survey. If the cultural soil is significantly different from the surrounding soil, a determination of $\mathrm{K}$ from field and laboratory soll analyses may be warranted. The LS is best estimated in the field with the use of simple surveying equipment, but an approximate value may be obtained from large-scale topographic maps of the site. The $C$ and $P$ values require an estimate of the percent cover by various plant canopy classes (1.e., grasses and weeds, brush, trees) and a recognition of any management practices applied to the site. Again, this information is best obtained on a site visit, but may be estimated from aerial photography. The $P$ value is primarily used to determine the probable decrease in soll erosion following initiation of an erosion-control program. 
36. There are limitations to the use of the USLE stemming from the way the original data were obtained. This empirical equation was developed by measuring erosion from hundreds of small plots across the country with different soils, slopes, crop/vegetation covers, etc. The average measured soil losses on these plots was 11.3 tons/acre, with a prediction error for the USLE at the test plots of 1.4 tons/acre ( 10 percent); 84 percent of the predictions were within 2 tons/acre of the measured soll loss (Wischmeier 1976). The USLE is a good guide for predicting long-term ( $>22$ years, or one rainfall cycle) soll loss from sheetwash or rill erosion. It is not intended to predict the exact short-term soil loss from a site by these processes, nor does it predict erosion by continuous gullies or stream channels. For this reason, predictions of soil loss based on the USLF are best used as indicators of the relative erosion hazards at a site.

37. The following calculations, using the appropriate nomographs and tables in this report, demonstrate the use of the USLE:

Site information:

$$
\begin{aligned}
& \text { Location near Omaha, Nebraska. } \quad R=150 \\
& \text { Silt loam soil } \\
& \text { Two slopes, each with 100-ft slope } \\
& \text { lengths } \\
& \text { Segment with } 3 \text {-percent slope (1V:33H) LS }=0.25 \\
& \text { Segment with 14-percent slope (1V:7H) LS }=2.2
\end{aligned}
$$

CASE 1: Bare soil (as at a construction site) without vegetation residue, untreated for soll conservation: $C=1 ; P=1$

A. 3-percent slope segment

$A=\operatorname{RKLSCP}=150 \times 0.35 \times 0.25 \times 1 \times 1=13$ tons/acre/year; or $200 \mathrm{~mm}$ of ground lowering per 100 years

B. 14-percent slope segment

$A=\operatorname{RKLSCP}=150 \times 0.35 \times 2.2 \times 1 \times 1=115$ tons/acre/year, or $1700 \mathrm{~mm}$ of ground lowering per 100 years, indicating an obvious need for erosion control or construction in the dry part of the year.

CASE 2: Fallow meadow, recently contour plowed, with 80-percent grass cover:

on the shallow slope: $\quad P=0.5$

on the steeper slope: $P=0.7$

A. 3-percent slope segment

$A=\operatorname{RKLSCP}=150 \times 0.35 \times 0.25 \times 0.013 \times 0.5=0.0085$ tons $/$ acre $/$ year, or $0.13 \mathrm{~mm}$ of ground lowering per 100 years 
B. 14-percent slope segment

$A=\operatorname{RKLSCP}=150 \times 0.35 \times 2.2 \times 0.013 \times 0.7=1.05$ tons $/$ acre $/$ year, or $16 \mathrm{~mm}$ of ground lowering per 100 years

CASE 3: Undisturbed forest, 70-percent canopy cover and 85-percent ground cover with herbaceous plants and duff: $C=0.002 ; P=1$

A. 3-percent slope segment

$A=\operatorname{RKLSCP}=150 \times 0.35 \times 0.25 \times 0.002 \times 1=0.026$ tons $/$ acre $/$ year or $0.4 \mathrm{~mm}$ of ground lowering per 100 years

B. 14-percent slope segment

$A=\operatorname{RKLSCP}=150 \times 0.35 \times 2.2 \times 0.002 \times 1=0.23$ tons $/$ acre $/$ year, or $3.5 \mathrm{~mm}$ of ground lowering per 100 years

38. These are simplified calculations for homogeneous slopes, with equally homogeneous ground cover and soll type. These are likely to be reasonable assumptions at most individual archeological sites, although not over an entire watershed. In the case of large areas, soll loss should be computed separately for each homogeneous area. Other special cases, such as runoff from snowmelt or extrapolation of $K$ values into mountainous regions of the western United States, require additional modifications to the equation. One should use Wischmeler and Smith (1978) and Wischmeier (1976) as detailed guides to the use of the USLE.

\section{Initiation of Gullying}

39. When surface runoff is significantly increased due to disturbance, the resulting runoff channel of ten takes the form of a gully. Gullies are rapidly eroding ephemeral channels with near-vertical sides and a relatively flat, actively shifting and eroding floor. A gully is an erosion hazard to an archeological site just as an actively eroding river channel is a threat. The loss of cultural sediments from gully erosion can be measured in terms of cubic metres of soll loss per square metre of site surface, rather than centimetres of soil loss per square metre of site surface as exemplified in the most severe erosion case calculated above. Gullies are discussed in this report for two reasons: first, because of their relation to surface erosion; and second, because (outside the arid western United States) they are characteristic of severely disturbed sites. Once runoff becomes so concentrated that gullies form on a site, the magnitude of erosion from the watershed and the effort required to control it increase significantly. Rilling of slopes 
above a swale can produce this concentration of runoff in thie swale, as can local shallow ground-water conditions. Gully initiation is then governed by the threshhold conditions of shear stress (valley slope $\times$ maximum water depth) and resistance to erosion (soil or bedrock strength, vegetation, etc.)

40. Another important property of gullies is that they may be either continuous, part of an integrated drainage network, or discontinuous. Continuous gullies grow as the base level lowers and erosion propagates from the mouth upslope, often in complex patterns of aggradation and degradation of the channel bed. Discontinuous gullies are more likely to form from local concentration of runoff and ground water at shallow depths. They propagate upstream in headcuts, which are vertical scarps between the undisturbed ground surface and the head of the gully channel. They are little affected by erosion elsewhere in the watershed until incorporated into a continuous drainage network. 41. Predicting where gullies will occur is not possible, although postdictive studies, such as those by Patton and Schumm (1975), Begin and Schumm (1979), or Graf (1979), have shown threshold relationships between gullied and ungullied conditions in the same watershed as functions of site conditions. Schumm and his colleagues concentrated on the driving force (shear stress) responsible for erosion, deriving a shear stress indicator $T_{0}$, which is proportional to the product of the drainage area (an indicator of relative discharge) and valley slope; $T_{0} \geq 1$ for gullied valley floors. The exponent on this relationship was equal to 0.26 in both cases tested, Piceance Creek in western Colorado and Medicine Creek in southwestern Nebraska; it is within accepted theoretical bounds based upon sediment transport and hydraulic geometry of stream channels. The constant of proportionality was $\sim 31$ in western Colorado and 110 in Nebraska, indicating that gullies form in valleys with lower slopes in Nebraska. This coefficient accounts for the variations in soll texture, vegetation, and runoff amounts and must be determined locally. For full details of this approach, see Schumm, Harvey, and Watson (1984). 42. A plot of the threshold relationship for each location is shown in Figure 9. The threshold was constructed using the lowest limit of all observed gullies in each region. Numerous ungullied watersheds were plotted above the gully transition threshold in both Colorado and Nebraska. These are meta-stable valleys and are likely to develop gullies in the future as a result of watershed disturbance and/or an extreme meteorological event. An 
analysis of this type should be performed for locations where cultural resources are at risk from development of a gully network in the watershed.

43. Graf (1979), studying small $\left(<5 \mathrm{~km}^{2}\right)$ watersheds in the Colorado Front Range, explicitly included the effect of vegetation in determining a gully threshold. He calculated a threshold shear stress (measure of erosion) proportional to the square of the blomass; the constant of proportionality was 0.1. Greater biomass resulted in ungullied valleys. Presumably, less biomass would be necessary to eliminate gullying from small storm events than during large storms. However, this hypothesis was not tested by Graf.

44. In these studies, threshold conditions could not be identified until they had exceeded a significant portion of the study area. Furthermore, there is no nationwide data base of threshold values for gully initiation as for surface erosion. In addition, gullies are landforms subject to positive feedback (self-perpetuation and growth) for a considerable time after initiation. Therefore, the best remedy for gullies is to treat them immediately after they form. Following the guidelines of Heede (1982), gully treatment requires: (a) stabilization of the gradients of continuous gullies beginning at the downstream end using check dams; (b) stabilization of headcuts in both continuous and discontinuous gullies with structural or semistructural means (rock or backsloping and willow planting, for example); and (c) establishment of vegetation on the gully bottom by planting, excluding grazing or ORV's, or allowing natural revegetation.

\section{Wind Erosion}

45. Wind erosion has its greatest impact on archeological sites when strong winds coincide temporally and spatially with unvegetated ground. Wind erosion has undoubtedly played some role in site formation processes in coastal regions and in the arid west and western Great Plains of this country. In the southwest, prehistoric temporary encampment sites in dune fields are moderately common (Wandsnider 1987); these provided good drainage and visibil1ty. Artifacts left at these sites were probably subject to geologically rapid burial as dunes moved over them, and exhumation of the artifacts is also controlled by dune movement. In this type of setting, site preservation has required the dunes to be stabilized; this has generally not worked. In areas outside of dune flelds where wind erosion is still significant, fine soil 
particles are often removed from the ground surface, concentrating larger and heavier artifacts at the surface in a geologic lag deposit (termed "desert pavement"). Over time, this compresses stratigraphic horizons as the ground surface deflates, while downwind solls thicken as they are enriched in windblown silt.

46. Erosion of soll by wind occurs in much the same way as erosion of soil by water; both are the result of a fluid moving over an erodible surface. There are two fundamental physical differences, however. First, the force of the moving fluid acting at the soll surface is a function of the overlying weight of the fluid. Higher untt weight and less turbulence in moving water more than compensates for the greater depth of the air layer, allowing water to transport larger particles. The velocity of wind necessary to entrain soil is greater than the threshold velocity of water to accomplish the same ends. Second, as anyone who has watched an actively moving sand dune knows, flowing air can move sand up substantial inclines more effectively than flowing water. Since wind erosion is generally of a lower magnitude, both areally and volumetrically, and less catastrophic than water erosion, less effort has been placed on systematic estimation of quantities of soil displaced by.wind. Locally, however, wind erosion is still a significant problem, and soil conservation research has resulted in a wind erosion equation with a form similar to that of the USLE (Woodruff and Siddoway 1965),

$$
E=\left(I^{\prime}, K^{\prime}, C^{\prime}, L^{\prime}, V\right)
$$

where

$$
\begin{aligned}
E= & \text { computed soil loss per unit area (tons/acre/year) } \\
I^{\prime}= & \text { soll erodibility index } \\
\mathrm{K}^{\prime}= & \text { soil ridge roughness factor ( } \mathrm{P} \text { In USLE) } \\
\mathrm{C}^{\prime}= & \text { climatic factor } \\
\mathrm{L}^{\prime}= & \text { field length along the prevalling wind direction (between } \\
& \text { windbreaks) } \\
\mathrm{V}= & \text { vegetation cover index }
\end{aligned}
$$

47. To show how wind erosion can compare with sheetwash erosion, imagine the site near Omaha, NE, used to demonstrate the USLE. Wind erosion 
on a 100-ft square plot of bare silt loam soll and a 3-percent slope, on a windward slope between a windbreak and a knoll, is calculated as follows:

$$
\begin{aligned}
& I^{\prime}= 98 \text { tons/acre/year for the lower two-thirds of the slope protected } \\
& \text { by the windbreak, } 127 \text { tons/acre/year for the next } 30 \text { percent of the } \\
& \text { slope, and } 147 \text { tons/acre/year for the remaining } 3 \text { percent at the } \\
& \text { knoll crest. (See Woodruff and Siddoway (1965) for correction } \\
& \text { factors for furrows, windbreaks, cohesive, or moist soil, etc.) } \\
& K^{\prime}=1 \text { for a bare, smooth field with no stubble or furrow ridges } \\
& C^{\prime}=0.015 \text { for Omaha, based on an equivalent wind energy map in Woodruff } \\
& \text { and Siddoway (1965) } \\
& L^{\prime}=107 \text { ft for a prevailing wind direction of } 159 \text { (NNW } \rightarrow \text { SSE) } \\
& V=1 \text { for an unvegetated field }
\end{aligned}
$$

so that

$$
\begin{aligned}
E_{1}= & I^{\prime} \times \mathrm{K}^{\prime} \times \mathrm{C}^{\prime} \\
= & {[(0.67 \times 98)+(0.3 \times 127)+(0.03 \times 147)] \times 1 \times 0.15 } \\
= & 16.2 \text { tons/acre/year } \\
\mathrm{E}_{2}= & \mathrm{E}_{1} \times\left(\mathrm{L}^{\prime}\right) \text { and must be solved graphlcally } \\
= & 3.5 \text { tons/acre/year } \\
\mathrm{E}_{3}= & \mathrm{E}_{2} \times(\mathrm{V}) \text { and must also be solved graphically } \\
= & 3.5 \text { tons/acre/year (or }<0.5 \text { tons/acre/year with } 3,000 \mathrm{lb} / \mathrm{acre} \text { of } \\
& \text { vegetation or applied mulch) }
\end{aligned}
$$

48. The $\sim 3.5$ tons of soil eroded by wind from this site per acre represents an additional 25-percent soll 1oss. Because these calculations are more complex than those for the USLE and fewer coefficients have been predetermined, the reader is referred to Woodruff and Siddoway (1965) for more discussion of the variables involved and for graphical solutions to the complex field length and vegetation functions. 
PART V: MANAGEMENT OF SURFACE EROSION AT ARCHEOLOGICAL SITES FOR SITE PRESERVATION PURPOSES

Management Goals

49. According to Thompson and Bettis (1983):

Since the notion of landscape stability pervades and biases cultural resource surveys, it also affects their management. Processes of erosion and alluvjation are ongoing; their past effects are visible and immediate. Therefore, it will not be always possible [sic] to manage and conserve these resources by avolding them, following what might be called a passive method of preservation that identifies surface constructions of any kind as threats while ignoring a direct and more pervasive threat from erosion. . . The writers suggest that cultural resources are more threatened on a reglonal scale by excessive soil erosion and unrestricted land use than by construction; the latter is just more public.

50. Management efforts at archeological sites with regard to soil erosion and surface disruption must be proportional to the intensity of potential disturbing processes. One such example is found at Fort Hood in which ongoing efforts to minimize surficial disturbance of sites where military maneuvers result in intense surface disturbance over the majority of the managed lands, have been equally intense and focused on two coordinated tasks.* First, a better definition of site boundaries was needed. Second, the archeologist needed an improved system to coordinate his site management activities with both those planning military maneuvers and the installation Director of Engineering and Housing. Managing this information has been accomplished with a data base manager and a two-part Geographic Information System (GIS), consisting of a Geographic Resource Analysis (GRASS) pixel-based system with environmental and digital elevation data and a vector-based Computer Aided Design (CAD) system for linear and other features with exact boundaries. The high resolution of this information management strategy allows explicit site avoldance in the course of training exercises and construction without restricting access to large areas of the reservation. This system is the basis for a Memorandum of Agreement between Fort Hood and the State Historic Preservation officer. Such intensive management has still resulted in site

* Personal Communication, 3 June 1988, Fred Briuer, Archeologist, Fort Hood, TX. 
damage (as noted previously); furthermore, it has required both a multiyear initial commitment of time and manpower and continuous updating to be useful, although this effort is shared by other environmental resource managers.

51. In order to effectively manage archeological sites to reduce surface erosion for site preservation purposes, cultural resource managers need to deal with two questions. First, what is the scientific significance of the resource? Second, how threatened are individual significant sites from surface erosion, and what is the resultant data loss? The remainder of this section seeks to address the decision-making process in these areas.

52. The first issue involves the oftentimes troublesome decisions related to determining significance of individual resource sites and eligibility for the National Register. Value judgments have been common in these deliberations. Are multicomponent sites more or less important than single component sites? Are occupational sites more or less important than single activity sites? The use of subjective criteria as those above is exemplified by Reed's (1987) example of significance ranking, appropriate for the Four Corners region of the American Southwest. Alternatively, cultural resource specialists and managers have spent considerable time and money over the past few years building data bases, management plans, and regional overviews to help provide scientific objectivity into determinations of significance. Excellent overviews such as that recently issued CE Southwest Division will greatly assist managers and specialists in making these critical decisions. Similarly, the various state cultural resource plans available through the state archeologist or state historic preservation office can be valuable resources as background information for evaluating significance of archeological sites.

53. Once a resource has been determined to be eligible to the NRHP, the second issue comes into play. Knowing the magnitude of expected erosion is the first step in determining the threat to the site. Estimating the threat to a site is more problematjc because a threshold of acceptable data loss must be made. The following priortty and treatment scheme is suggested. The scheme is based upon a tolerance of no data loss and lowering of the ground surface by $0.15 / \mathrm{mm} /$ ton of calculated currert annual soil 1oss. The annual soll loss is based on application of the USLF. 
a. Priority 1. Presently eroding sites with salvageable data: treat immediately.

b. Priority 2. Sites with impending data loss within next 2 years: plan treatment immediately and execute next FY.

c. Priority 3. Sites with impending data loss in 2 to 10 years: plan treatment this FY, execute prior to data loss.

d. Priority 4. Sites with impending data loss in $>10$ years: passive management (avoidance) currently appropriate, but reassess if site conditions change.

\section{Management Options}

54. Once management decisions have identified which sites are significant and which of those sites are threatened by surface erosion effects, further decisions must be made regarding what type of active management must be initiated for those sites to be preserved. For certain sites, those in the Priority 1 status, the forces of erosion may be serious enough to bring about mitigation of those impacts through a data recovery program. However, if erosion can be corrected or controlled, attempts should be made to preserve the remaining cultural materials in place. The primary goal of erosion control is to reduce the shear stress of water exerted on the ground surface by increasing vegetative cover (to strengthen the soil, increase the infiltration capacity, and dissipate the energy of rain or overland flow) and decreasing the ground slope and/or effective slope length at the site. The impact of erosion or surface disturbance from adjacent areas to the site also needs to be evaluated. Fortunately for managers, surface erosion control technology is the best developed and is the least expensive means of erosion control to implement.

55. Thorne, Fay, and Hester (1987) give a review of numerous techniques applicable to site preservation. of these, revegetation is the most useful in controlling surface erosion. Useful information for stabilizing soll materials and selecting species for use on CE civil works projects and military installations can be found in reports by Lee et al. (1985), Doerr and Landin (1985), and Environmental Laboratory (1986). Along with revegetation, it may be necessary to delete acreage from grazing or agricultural lease areas to protect Individual sites. Structural stabilization is rarely needed for surface erosion control, but may be necessary if gullies are impinging on the 
site or are in danger of doing so. In some cases, burial or capping of the site with culturally sterile fill may be advisable to provide both protection to the exposed site surface and a base for the revegetation effort. Care should be taken, however, to ensure that burial does not create an adverse effect to the site due to compaction from the overburden of the added soil, construction equipment, or changes in the transient ground-water regime and associated changes in soil chemistry.

56. Whatever the management option selected to provide preservation of an archeological site experiencing loss of data due to surface erosion, provisions should be made for monitoring of the location. Monitoring is necessary to ensure continued protection of the resource and to provide feedback on the success of the preservation strategy. Some minor maintenance may be required at either specified or as needed intervals to assure long-term protection. 
Begin, Z. B., and Schumm, S. A. 1979. "Instability of Alluvial Valley Floors: A Method for Its Assessment," Transactions of the American Society of Archeology Engineers, Vo1 22, pp 347-350.

Bocek, B. 1986. "Rodent Ecology and Burrowing Behavior: Predicted Effects on Archeological Site Formation," American Antiquity, Vol 51, No. 3, pp 589-603.

Brady, N. C. 1984. "Some Important Physical Properties of Nineral Solls," The Nature and Froperties of Solls, 9th ed., Macmillan, New York, pp 36-71. Carlson, D. L., and Briuer, F. I. 1986. "Analysis of Military Training Impacts on Protected Archeological Sites at West Fort Hood, Texas, "US Army Fort Hood Archeological Resource Management Series Research Report No. 9, Fort Hood, TX.

Dietrich, W. E., and Dunne, T. 1978. "Sediment Budget for a Small Catchment in Mountainous Terrain," Zeitschrift Fur Geomorphologie Supplementband 29, pp 191-206.

Doerr, T. B., and Landin, M. C. 1985. "Recommended Species for Vegetative Stabilization of Training Lands in Arid and Semi-Arid Environments, "Technical Report N-85/15, US Army Engineer Construction Engineering Research Laboratory, Champaign, IL.

Dunne, T. 1970. "Runoff Production in a Humid Area," US Department of Agriculture Publication ARS-41-160, US Government Printing office, Washington, DC.

Dunne, T., and Leopold, L. B. 1978. Water in Environmental Planning, W. H. Freeman and Co., San Francisco, CA.

Emmett, W. W. 1978. "Overland Flow," Hillslope Hydrology, John Wiley and Sons, Chichester, UK, pp 145-176.

Environmental Laboratory. 1986. "Fleld Gulde for Low Maintenance Vegetation Establishment and Management," Instruction Report R-86-2, US Army Engineer Waterways Experiment Station, Vicksburg, MS.

Ford, J. L., and Rolingson, M. A. 1972. "Investigation of Destruction to Prehistoric Sites Due to Agricultural Practices in Southeastern Arkansas 1970 - 1971," Publications on Archeology Research Series No. 3, Arkansas Archeological Survey, Little Rock, AR, pp $1-40$. Goudie, A. 1982. The Human Impact: Man's Role in Environmental Changc, MIT
Press, Cambridge, MA.

Graf, W. L. 1979. "The Development of Montane Arroyos and Gullies," Earth Surface Processes, Vol 4, No. 1, pp 1-14.

Hack, J. T., and Goodlett, J. C. 1960. "Geomorphology and Forest Ecology of a Mountain Region in the Central Appalachians," US Geological Survey Professional Paper 347, US Government Printing Office, Washington, DC.

Heede, B. H. 1982. "Gully Control: Determining Treatment Priorities for Gullies in a Network," Environmental Management, Vol 6, No. 5, pp 441-451. 
Higgins, C. 1979. "Terracettes: A Classification," Geological Soclety of America Abstracts with Programs, Vol 11, No. 7, pp 443-444.

Ho1t, H. B. 1987. "Federal Archeology Today: Survey Requirements and Predictive Alternatives," American Archeology, Vo1 6, No. 2, pp 131-139.

Knoer1, J. J., and Versagg1, N. 1984. "Plow Zone Sites: Research Strategies and Management Policy," American Archeology, Vol 4, No. 1, pp 76-80.

Lee, Charles R., Skogerboe, John G., Eskew, Kurt, Price, Richard A., Page, Norwood R., Clar, Michael, Kort, Robert, and Hopkins, Homer. 1985.

"Restoration of Problem Soil Materials at Corps of Engineers Construction Sites," Instruction Report EL-85-2, US Army Engineer Waterways Experiment Station, Vicksburg, MS.

Marron, D. C. 1985. "Colluvium in Bedrock Hollows on Steep Slopes, Redwood Creek Drainage Basin, Northwestern California," Soils and Geomorphology; Catena Supplement 6, pp 59-68.

- 1987. "Floodplain Storage of Metal-Contaminated Sediments Downstream of a Gold Mine at Lead, South Dakota," Chemical Quality of Water and the Hydrologic Cycle, Lewis Publishers, Chelsea, MI, pp 193-209.

McManamon, F. P. 1984. "The Integrity of Plowzone Sites," American Archeology, Vol 4, No. 1, pp 70-76.

Medford, L. D. 1972. "Agricultura? Destruction of Archeological Sites in Northeast Arkansas," Publications on Archeology Research Series No. 3, Arkansas Archeological Survey, Little Rock, AR, pp 41-82.

Meyer, L. D., and Ports, M. A. 1976.- "Prediction and Control of Urban. Erosion and Sedimentation," National Symposium on Urban Hydrology, Hydraulics, and Sedimentation Proceedings, University of Kentucky Bulietin III, Lexington, KY, pp 323-331.

Moeyersons, J. 1978. "The Behavior of Stones and Stone Implements, Buried in Consolidating and Creeping Kalahari Sands," Earth Surface Processes, Vol 3, No. 2, pp 115-128.

Nelson, S. M., Plooster, M., and Ford, D. L. 1987. "An Interactive Computer Graphic Technique for Identifying Occupation Surfaces in Deep Archeological Sites," Journal of Field Archaeology, Vo1 14, pp 353-358.

Nickens, F. R., and Chandler, S. M. 1987. "Development and Use of LargeScale Regional Sampling and Predictive Modeling on the Northern Colorado Plateau," American Archeology, Vo1 6, No. 2, pp 151-159.

Ode11, G. H., and Cowan, F. 1987. "Estimating Tillage Effects on Artifact Distributions," American Antiquity, Vol 52, No. 2, pp 456-484.

Patton, P. C., and Schumm, S. A. 1975. "Gully Erosion, Northwestern Colorado: A Threshold Phenomenon," Geology, Vol 3, No. 2, pp 88-90.

Redman, C. L. 1987. "Surface Collection, Sampling, and Research Design: A Retrospective," American Antiquity, Vol 52, No. 2, pp 249-265.

Reed, A. D. 1987. "A Technique for Ranking Prehistoric Sites in Terms of Scientific Significance," American Archeology, Vol 6, No. 2, pp 127-130.

Schiffer, M. B. 1983. "Toward the Identification of Formation Processes," American Antiquity, Vol 48, No. 4, pp 675-706. 
Schlanger, S. H., and Orcutt, J. D. 1986. "Site Surface Characteristics and Functional Inferences," American Antiquity, Vol 51, No. 2, pp 296-312.

Schumm, S. A., Harvey, M. D., and Watson, C. C. 1984. Incised Channels: Morphology, Dynamics and Control, Water Resources Publications, Littleton, Co.

Swanson, F. J., Janda, R. J., Dunne, T., and Swanston, D. N. 1982. "Sediment Budgets and Routing in Forested Drainage Basins," USDA Forest Service General Technical Report PNW-141, Portland, OR.

Terry, R. D., and Chillinger, G. V. 1955. "Summary of 'Concerning Some Additional Aids in Studying Sedimentary Formations' by M. S. Shvetsov," Journal of Sedimentary Petrography, Vo1 25, No. 3, pp 229-234.

Thompson, D. M., and Bettis, E. A., III. 1983. "Out of Sight, Out of Planning: Assessing and Protecting Cultural Resources in Evolving Landscapes," Contracts Abstracts and CRM Archeology, Vol 2, No. 3, pp 16-22.

Thorne, R. M., Fay, P. M., and Hester, J. J. 1987 (May). "Archeological Site Preservation Techniques: A Preliminary Review," Technical Report E-87-3, US Army Engineer Waterways Experiment Station, Vicksburg, MS.

Trimble, S. W. 1975. "Denudation Studies: Can We Assume Stream Steady State?" Science, Vo1 188, No. 4194, pp 12.07-1208.

Wandsnider, L. A. 1987. "Experimental Investigations of Artifact Behavior in Albuquerque West Mesa Dune Fields," Secrets of a City: The Archeological Society of New Mexico, Report No. 13, pp 174-191.

Wischmeier, W. H. 1976. "Use and Misuse of the Universal Soil Loss Equation," Journal of Soil and Water Conservation, Vol 31, No. 1, pp 5-9.

Wischmeier, .W. H., and Mannering, J. V. 1965. "Effect of Organic Matter Content of the Soll on Infiltration," Journal of Soil and Water Conservation, Vo1 20, No. 4, pp 150-152.

Wischmeier, W. H., and Smith, D. D. 1978. "Predicting Rainfall Erosion Losses--A Guide to Conservation Planning," USDA Agricultural Handbook No. 537, US Government Printing Office, Washington DC.

Wishy, B., and Leuchtenburg, W. E., eds. 1977. Notes on the State of Virginia, by Thomas Jefferson, Harper and Row, New York.

Wolman, M. G., and Schick, A. P. 1967. "Effects of Construction on Fluvial Sediment, Urban and Suburban Areas of Maryland," Water Resources Research, Vol 3, No. 2, pp 451-464.

Womack, W. R., and Schumm, S. A. 1977. "Terraces of Douglas Creek, Northwestern Colorado: An Example of Episodic Erosion," Geology, Vol 5, No. 2, pp 72-76.

Wood, W. R., and Johnson, D. L. 1978. "A Survey of Disturbance Processes in Archeological Site Formation," Advances in Archeological Method and Theory, Vo1 1, pp 315-381.

Woodruff, N. P., and Siddoway, F. H. 1965. "A Wind Erosion Equation," Soll Science Society of America Proceedings, Vol 29, pp 602-608. 
Table 1

Mulch Factors and Length Limits for Construction Slopes*

\begin{tabular}{|c|c|c|c|c|}
\hline Type of Mulch & $\begin{array}{l}\text { Mulch Rate } \\
\text { tons/acre }\end{array}$ & Land Slope, \% & Factor C & $\begin{array}{c}\text { Length } \\
\text { Limit**, ft }\end{array}$ \\
\hline None & 0 & a11 & 1.0 & -- \\
\hline Straw or hay, & 1.0 & $1-5$ & 0.20 & 200 \\
\hline $\begin{array}{l}\text { tied down by } \\
\text { anchoring and }\end{array}$ & 1.0 & $6-10$ & 0.20 & 100 \\
\hline tacking & 1.5 & $1-5$ & 0.12 & 300 \\
\hline equipment $\dagger$ & 1.5 & $6-10$ & 0.12 & 150 \\
\hline Do. & 2.0 & $1-5$ & 0.06 & 400 \\
\hline & 2.0 & $6-10$ & 0.06 & 200 \\
\hline & 2.0 & $11-15$ & 0.07 & 150 \\
\hline & 2.0 & $16-20$ & 0.11 & 100 \\
\hline & 2.0 & $21-25$ & 0.14 & 75 \\
\hline & 2.0 & $26-33$ & 0.17 & 50 \\
\hline & 2.0 & $34-50$ & 0.20 & 35 \\
\hline Crushed stone, & 135 & $<16$ & 0.05 & 200 \\
\hline $1 / 4$ to $11 / 2$ in. & 135 & $16-20$ & 0.05 & 150 \\
\hline & 135 & $21-33$ & 0.05 & 100 \\
\hline & 135 & $34-50$ & 0.05 & 75 \\
\hline Do. & 240 & $<21$ & 0.02 & 300 \\
\hline & 240 & $21-33$ & 0.02 & 200 \\
\hline & 240 & $34-50$ & 0.02 & 150 \\
\hline Wood chips & 7 & $<16$ & 0.08 & 75 \\
\hline & 7 & $16-20$ & 0.08 & 50 \\
\hline Do. & 12 & $<16$ & 0.05 & 150 \\
\hline & 12 & $16-20$ & 0.05 & 100 \\
\hline & 12 & $21-33$ & 0.05 & 75 \\
\hline Do. & 25 & $<16$ & 0.02 & 200 \\
\hline & 25 & $16-20$ & 0.02 & 150 \\
\hline & 25 & $21-33$ & 0.02 & 100 \\
\hline & 25 & $34-50$ & 0.02 & 75 \\
\hline
\end{tabular}

* From Meyer and Ports (1976). Developed by an interagency workshop group on the basis of field experfence and limited research data.

** Maximum slope length for which the specified mulch rate is considered effective. When this limit is exceeded, either a higher application rate or mechanical shortening of the effective slope length is required.

$\dagger$ When the straw or hay mulch is not anchored to the soil, $C$ values on moderate or steep slopes of solls having $K$ values greater than 0.30 should be taken at double the values given in this table. 
Table 2

Factor C for Permanent Pasture, Range, and Idle Land*

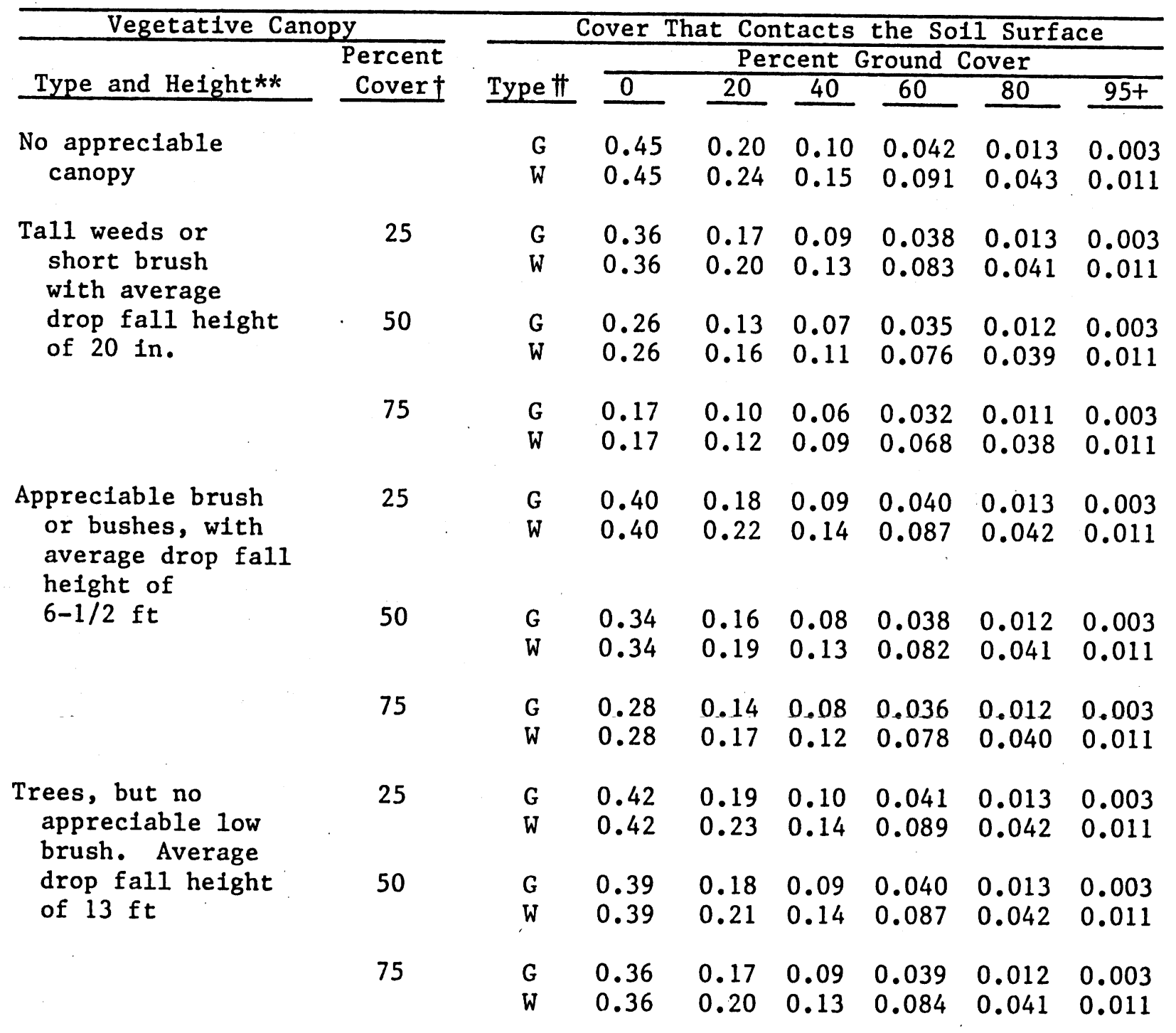

Source: Wischmeler and Smith (1978).

* The listed $C$ values assume that the vegetation and mulch are randomly distributed over the entire area.

** Canopy height is measured as the average fall height of water drops falling from the canopy to the ground. Canopy effect is inversely proportional to drop fall height and is negligible if fall height exceeds $33 \mathrm{ft}$.

$\dagger$ Portion of total-area surface that would be hidden from view by canopy in a vertical projection (a bird's-eye view).

\# $G=$ cover at surface is grass, grasslike plants, decaying compacted duff, or litter at least 2 in. deep.

$\mathrm{W}=$ cover at surface is mostly broadleaf herbaceous plants (as weeds with little lateral-root network near the surface) or undecayed residues or both. 
Table 3

Factor C for Undisturbed Forest Land*

\begin{tabular}{ccc}
\hline $\begin{array}{c}\text { Percent of Area } \\
\text { Covered by Canopy of } \\
\text { Trees and Undergrowth }\end{array}$ & $\begin{array}{c}\text { Percent of Area } \\
\text { Covered by Duff } \\
\text { at Least 2 in. Deep }\end{array}$ & Factor C** \\
\hline $100-75$ & $100-90$ & $0.0001-0.001$ \\
$70-45$ & $85-75$ & $0.002-0.004$ \\
$40-20$ & $70-40$ & $0.003-0.009$
\end{tabular}

Source: Wischmeier and Smith (1978).

* Where effective 11tter cover is less than 40 percent or canopy cover is less than 20 percent, use Table 6 in Wischmeler and Smith (1978). Also use Table 6 where woodlands are being grazed, harvested, or burned.

** The ranges in listed $C$ values are caused by the ranges in the specifled forest litter and canopy covers and by variations in effective canopy heights.

Table 4

$\underline{\text { P Values and Slope-Length Limits for Contouring }}$

\begin{tabular}{|c|c|c|}
\hline $\begin{array}{c}\text { Land Slope } \\
\text { percent } \\
\end{array}$ & $\underline{P}$ Value & $\begin{array}{c}\text { Maximum Length* } \\
\mathrm{ft}\end{array}$ \\
\hline 1 to 2 & 0.60 & 400 \\
\hline 3 to 5 & 0.50 & 300 \\
\hline 6 to 8 & 0.50 & 200 \\
\hline 9 to 12 & 0.60 & 120 \\
\hline 13 to 16 & 0.70 & 80 \\
\hline 17 to 20 & 0.80 & 60 \\
\hline 21 to 25 & 0.90 & 50 \\
\hline
\end{tabular}

Source: Wischmeler and Smith (1978).

* Limit may be increased by 25 percent if residue cover after crop seedlings will regularly exceed 50 percent. 
Table 5

$\underline{P}$ Values, Maximum Strip Widths, and Slope-Length

Limits for Contour Stripcropping

\begin{tabular}{|c|c|c|c|c|c|}
\hline \multirow{2}{*}{$\begin{array}{l}\text { Land Slope } \\
\text { percent }\end{array}$} & \multicolumn{3}{|c|}{ P Values* } & \multirow{2}{*}{$\begin{array}{l}\text { Strip Width** } \\
\mathrm{ft} \\
\end{array}$} & \multirow{2}{*}{$\begin{array}{c}\text { Maximum Length } \\
\mathrm{ft} \\
\end{array}$} \\
\hline & $\mathrm{A}$ & $\mathrm{B}$ & $C$ & & \\
\hline 1 to 2 & 0.30 & 0.45 & 0.60 & 130 & 800 \\
\hline 3 to 5 & 0.25 & 0.38 & 0.50 & 100 & 600 \\
\hline 6 to 8 & 0.25 & 0.38 & 0.50 & 100 & 400 \\
\hline 9 to 12 & 0.30 & 0.45 & 0.60 & 80 & 240 \\
\hline 13 to 16 & 0.35 & 0.52 & 0.70 & 80 & 160 \\
\hline 17 to 20 & 0.40 & 0.60 & 0.80 & 60 & 120 \\
\hline 21 to 25 & 0.45 & 0.68 & 0.90 & 50 & 100 \\
\hline
\end{tabular}

Source: Wischmeier and Smith (1978).

* $\mathrm{P}$ values:

$A=$ for 4-year rotation of row crop, small grain with meadow seeding, and 2 years of meadow. A second row crop can replace the small grain if meadow is established in it.

$B=$ for 4-year rotation of 2 years row crop, winter grain with meadow seeding, and 1-year meadow.

$C=$ for alternate strips of row crop and small grain.

** Adjust strip-width limit, generally downward, to accommodate widths of farm equipment. 
Table 6

$\underline{P}$ Values for Contour-Farmed Terraced Fields*

\begin{tabular}{|c|c|c|c|c|}
\hline \multirow[b]{2}{*}{$\begin{array}{l}\text { Land Slope } \\
\text { percent }\end{array}$} & \multicolumn{2}{|c|}{ Farm Planning } & \multicolumn{2}{|c|}{ Computing Sediment Yleld $\dagger$} \\
\hline & \begin{tabular}{l}
\multicolumn{1}{c}{ Farm } \\
Contour \\
Factor** \\
\end{tabular} & $\begin{array}{l}\text { anning } \\
\text { Stripcrop } \\
\text { Factor } \\
\end{array}$ & $\begin{array}{l}\text { Graded Channels } \\
\text { Sod Outlets } \\
\end{array}$ & $\begin{array}{c}\text { Steep Backslope } \\
\text { Underground } \\
\text { Outlets } \\
\end{array}$ \\
\hline 1 to 2 & 0.60 & 0.30 & 0.12 & 0.05 \\
\hline 3 to 8 & 0.50 & 0.25 & 0.10 & 0.05 \\
\hline 9 to 12 & 0.60 & 0.30 & 0.12 & 0.05 \\
\hline 13 to 16 & 0.70 & 0.35 & 0.14 & 0.05 \\
\hline 17 to 20 & 0.80 & 0.40 & 0.16 & 0.06 \\
\hline 21 to 25 & 0.90 & 0.45 & 0.18 & 0.06 \\
\hline
\end{tabular}

Source: Wischmeier and Smith (1978).

* Slope length is the horizontal terrace interval. The listed values are for contour farming. No additional contouring factor is used in the computation.

** Use these values for control of interterrace erosion within specified soll loss tolerances.

$\dagger$ These values include entrapment efficiency and are used for control of offsite sediment within limits and for estimating the field's contribution to watershed sediment yield. 
Table 7

Variables and Values for Ranking Site Significance in

East-Central Utah

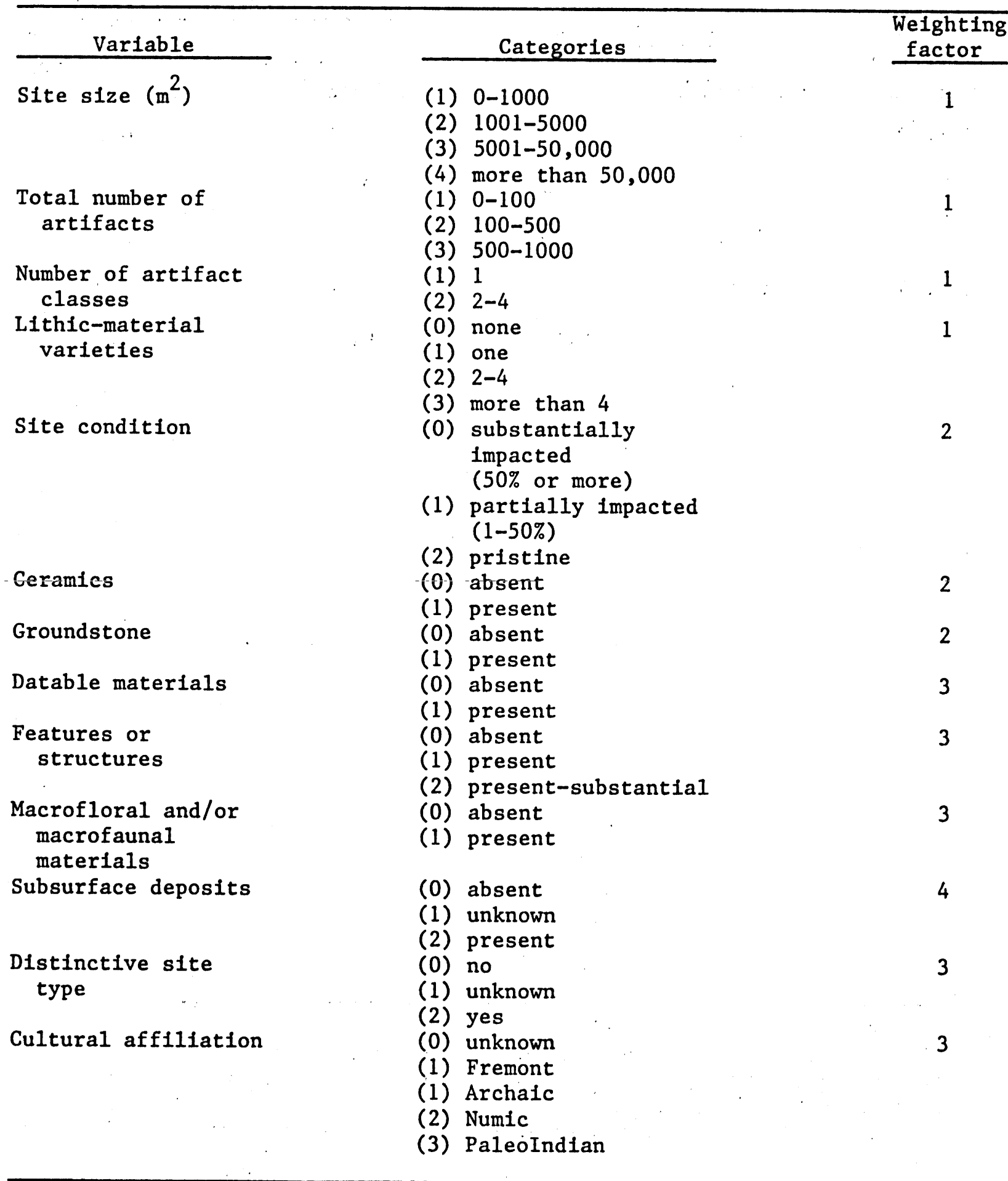

Source: Reed (1987) (Courtesy of American Archeology). 


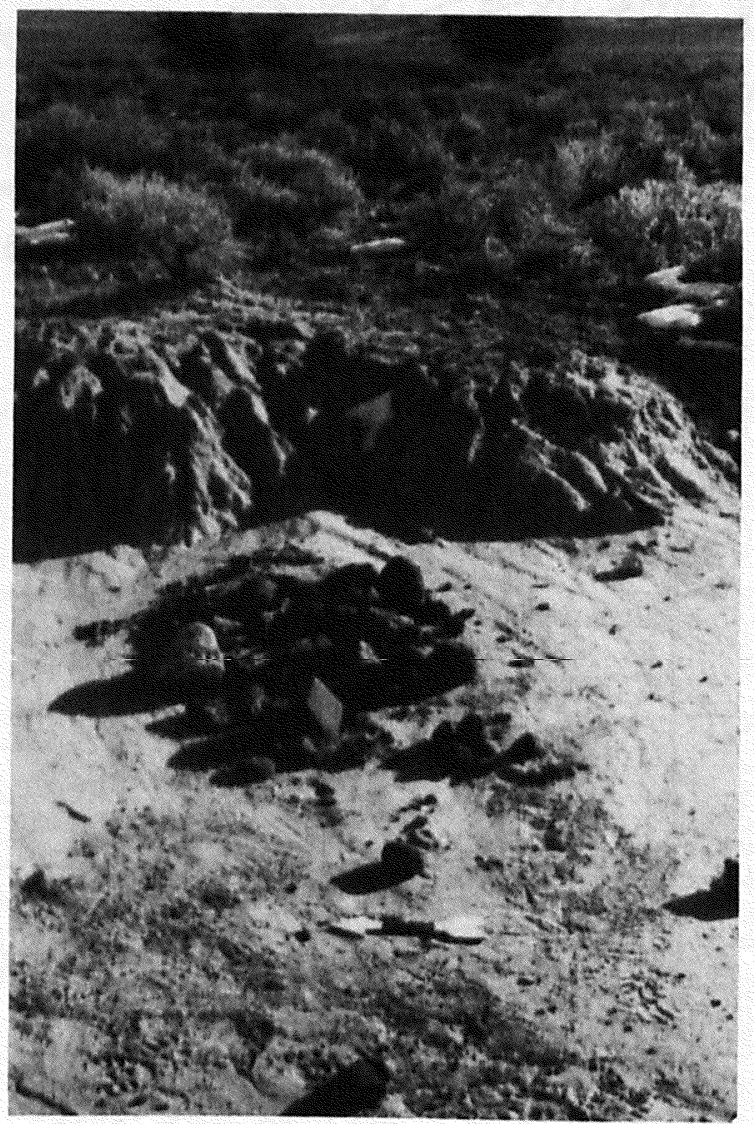

Figure 1. Roasting pit with archeological context removed, Indian Creek Site 5ME1373, western Colorado (photo courtesy of Paul R. Nickens) 


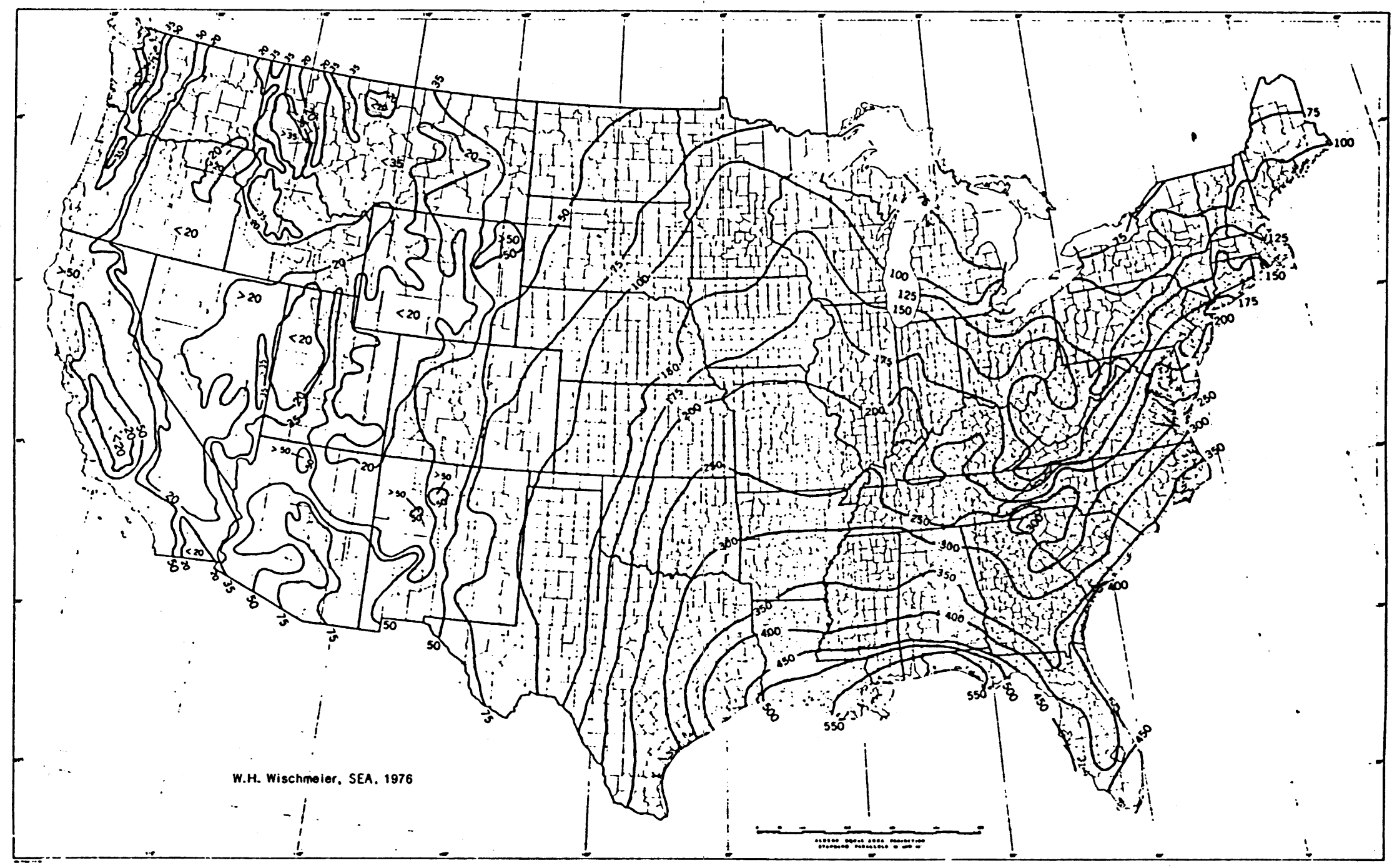

Figure 2. Average annual values of the rainfall erosion index (Wischmeier and Smith 1978) 


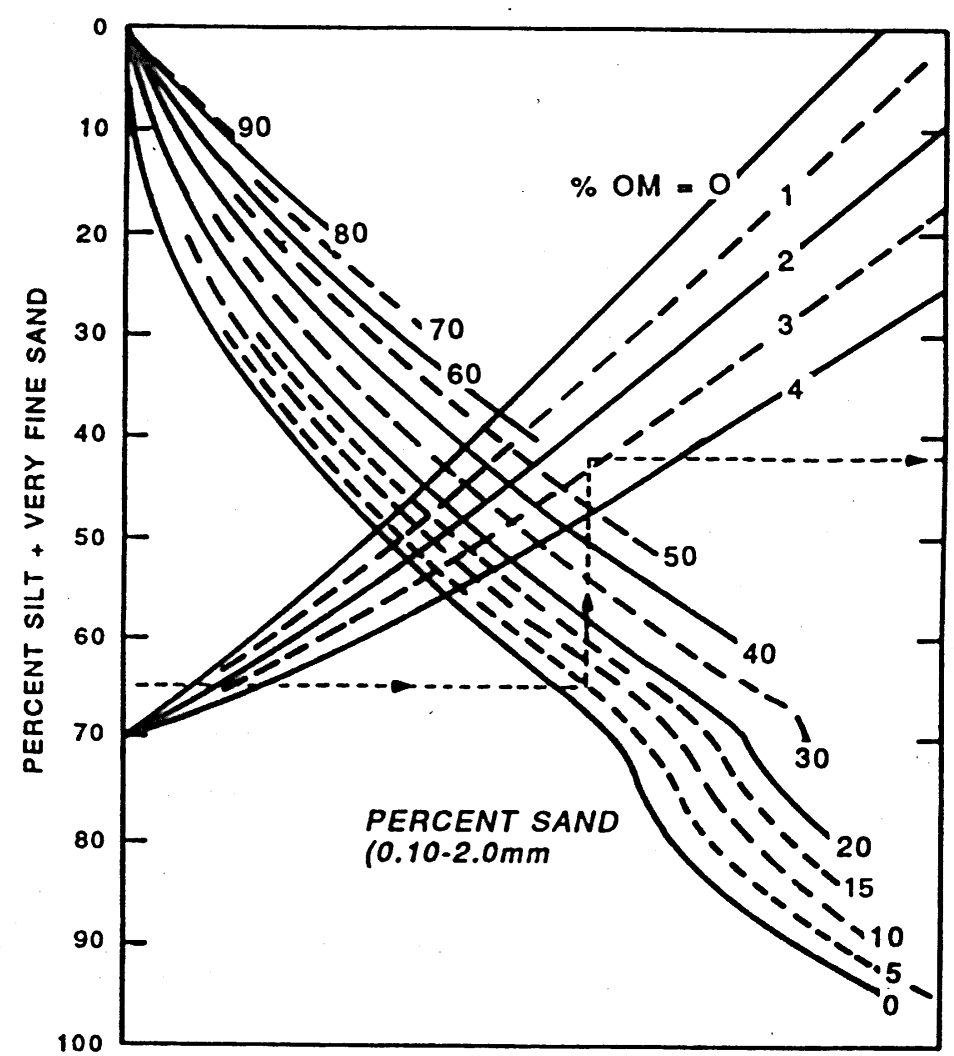

PROCEDURE: WITH APPROPRIATE DATA ENTER SCALE AT LEFT AND PROCEED TO POINTS REPRESENTING THE SOIL'S \% SAND $(0.10-2.0 \mathrm{~mm}) . \%$ ORGANIC MATTEP. STRUCTURE, AND PERMEABILITY. IN THAT SEQUENCE. INTERPOLATE BETWEEN PLOTTED CURVES THE DOTTED LINE ILLUSTRATES PROCEDURE FOR SOIL HAVING: SI+VFS 65\%. SAND $5 \%$ OM $2.8 \%$. STRUCTURE 2, PERMEA

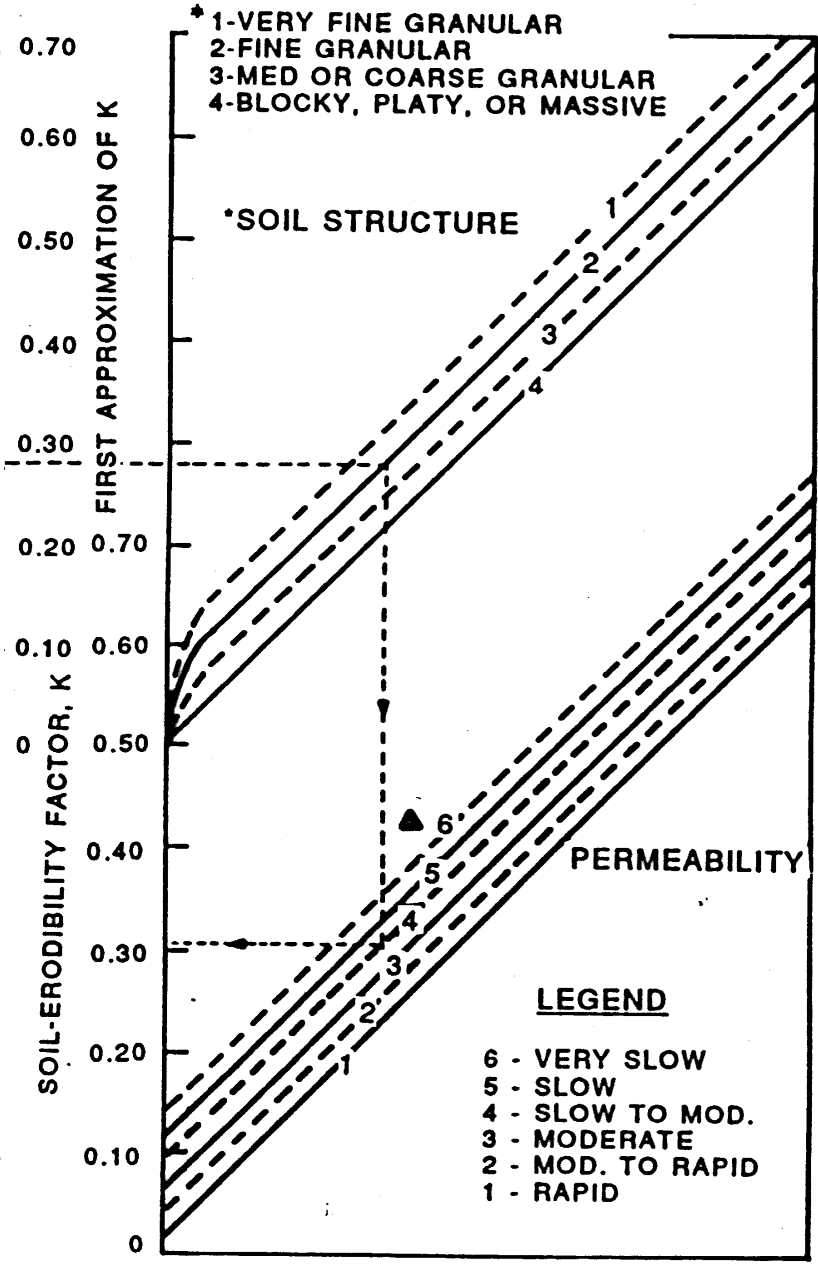
BILITY 4. SOLUTION: $K=0.31$.

Figure 3. The soll-erodibility nomograph. Where the silt fraction does not exceed 70 percent, the equation is $100 \mathrm{~K}=2.1 \mathrm{M}^{1.14}\left(10^{-4}\right)(12-a)+3.25(b-2)+2.5(c-3)$, where $M=$ (percent of silt and very fine silt) (100-percent $c), a=$ percent organic matter, $b=$ structure code, and $c=$ profile permeability class (Wischmeier and Smith 1978) 


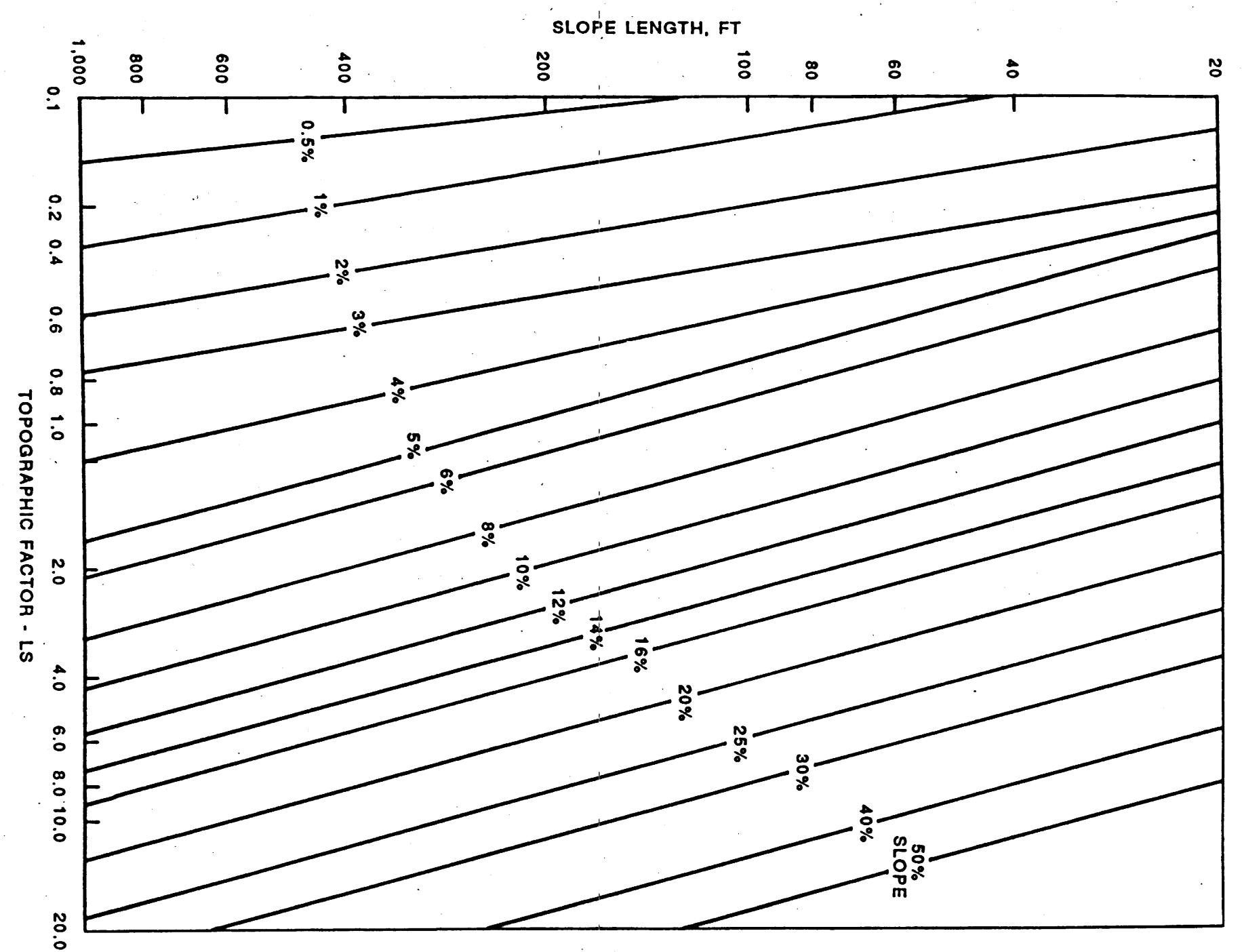

Figure 4. Slope-effect chart (topographic factor LS). LS $=(\lambda / 72.6)^{\mathrm{m}}\left(65.41 \sin ^{2} \theta+4.56 \sin \mathrm{g} \theta\right.$ $+0.065)$, where $\lambda=$ slope length in feet, $\theta=$ slope angle $(100 \times \tan \theta=$ gradient in percent) and $\mathrm{m}=0.2$ for gradients $<1$ percent, 0.3 for 1 - to 3 -percent slopes, 0.4 for 3.5- to 4.5-percent slopes, and 0.5 for slopes of 5 percent or steeper (Wischmeier and Smith 1978) 


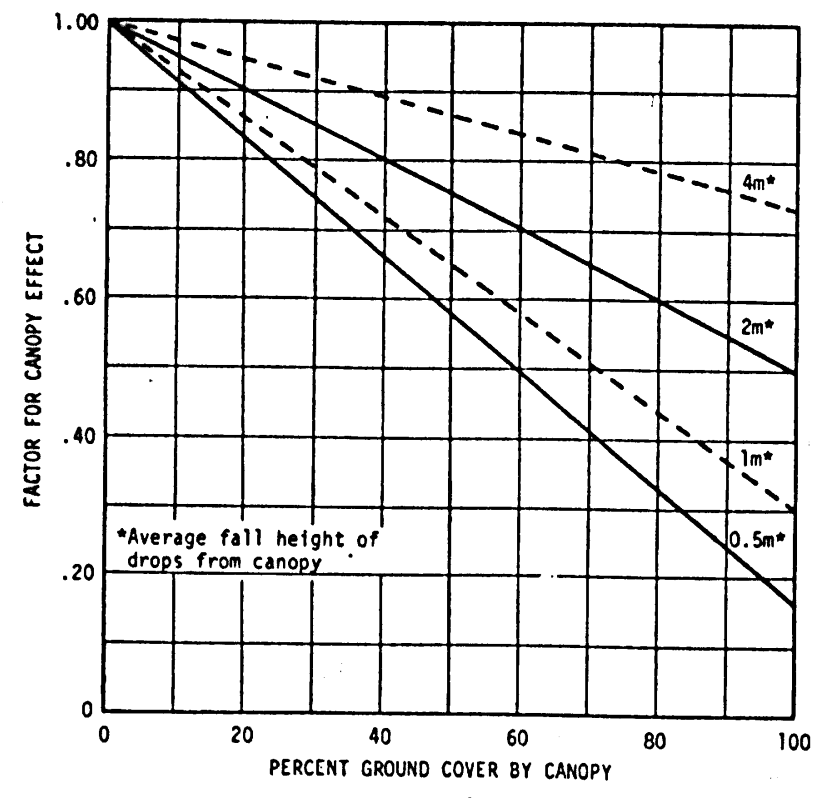

Figure 5. Influence of vegetative canopy on effective $\mathrm{E} 1$ values. Canopy factor is a subfactor of $C$ (Wischmeier and Smith 1978)

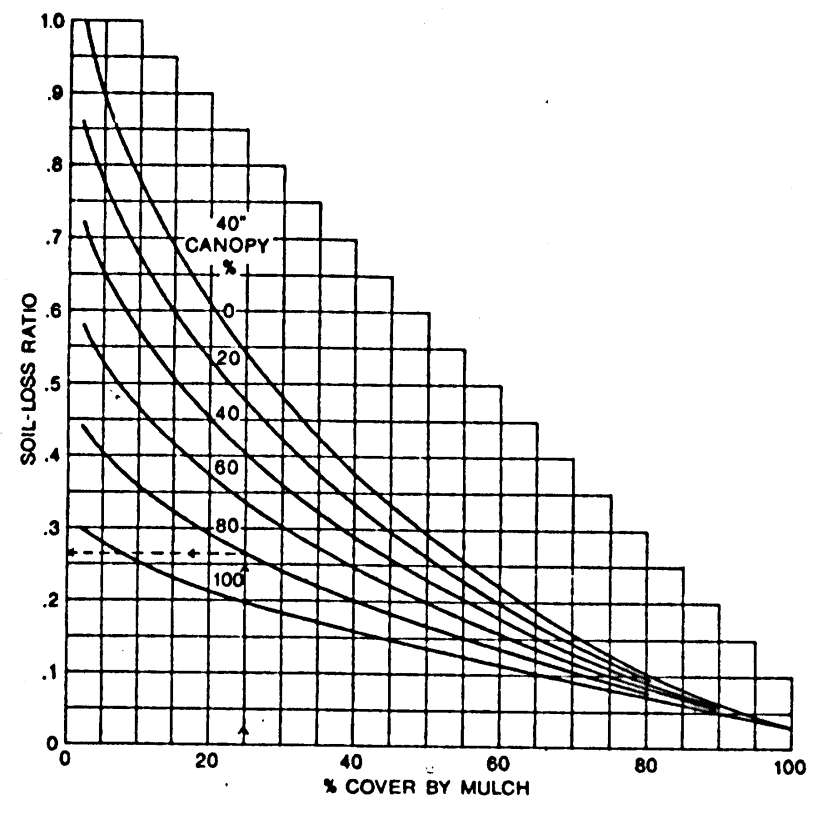

Figure 6. Combined mulch and canopy effects when average fall distance of drops from canopy to the ground is about 40 in. ( $1 \mathrm{~m}$ ) (Wischmeier and Smith 1978)

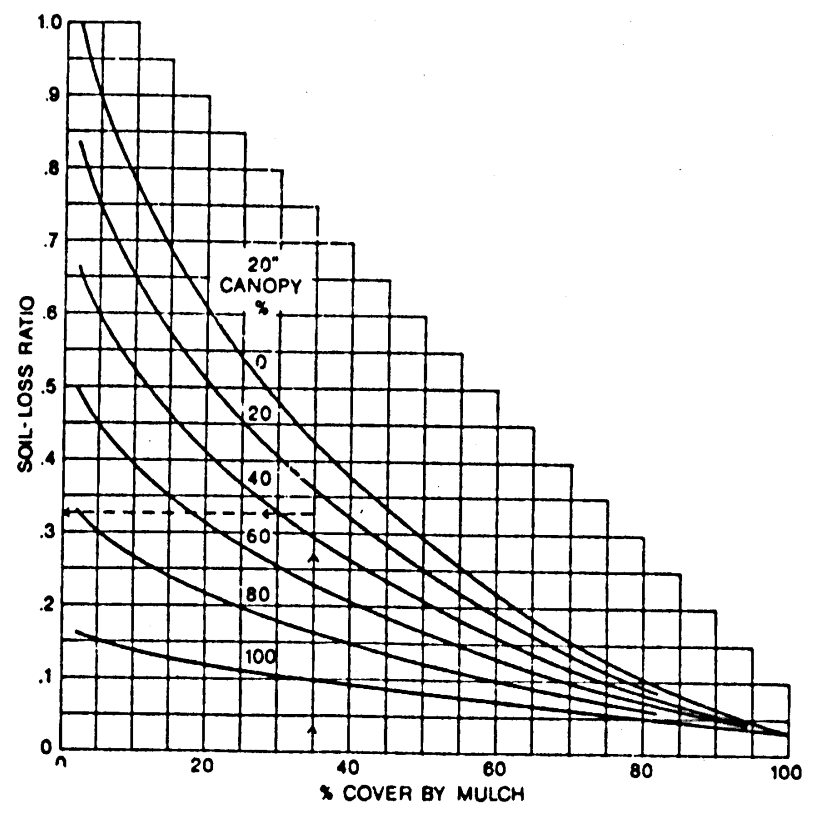

Figure 7. Combined mulch and canopy effects when average fall distance of drops from canopy to the ground is about 20 in. $(0.5 \mathrm{~m}$ ) (Wischmeier and Smith 1978) 


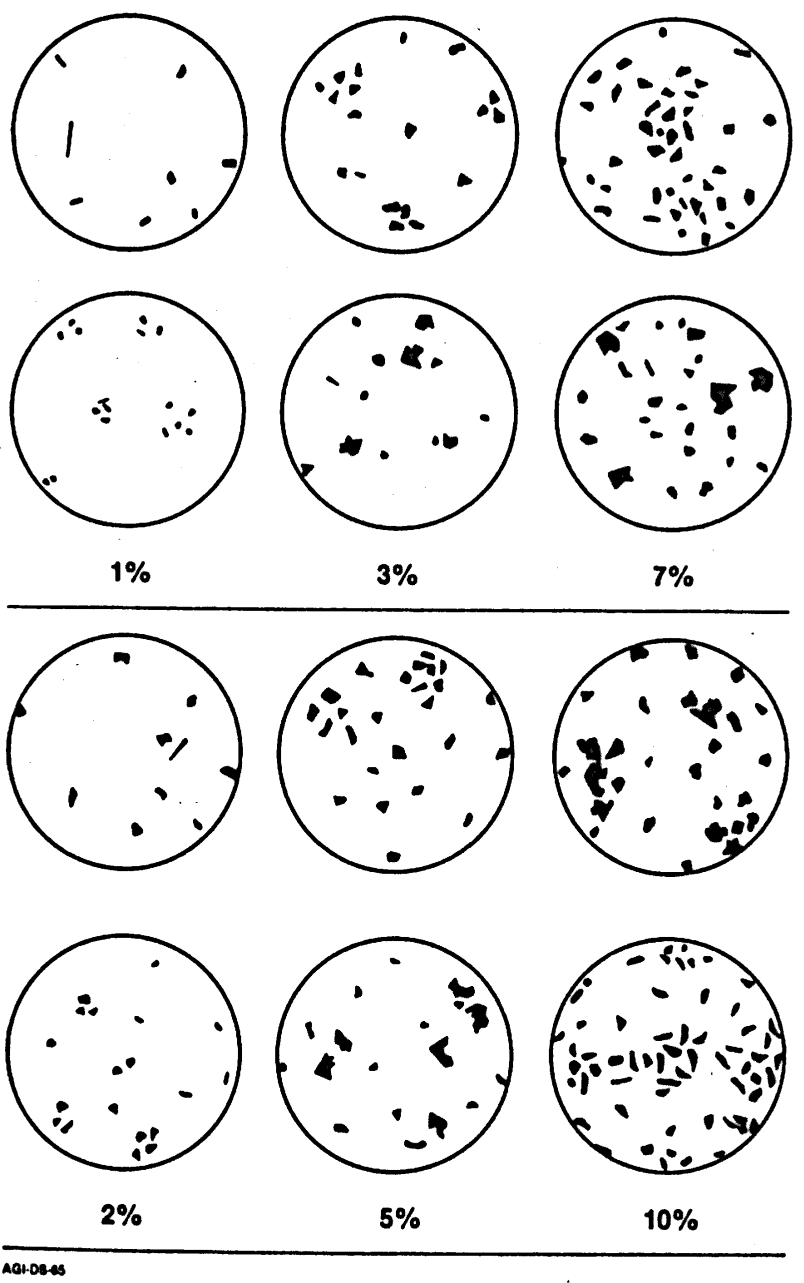

a. American Geological Institute (AGI) data sheet 15.1

Figure 8. Comparison charts for estimating percentage of ground cover (Terry and Chillinger 1955) (Continued) 


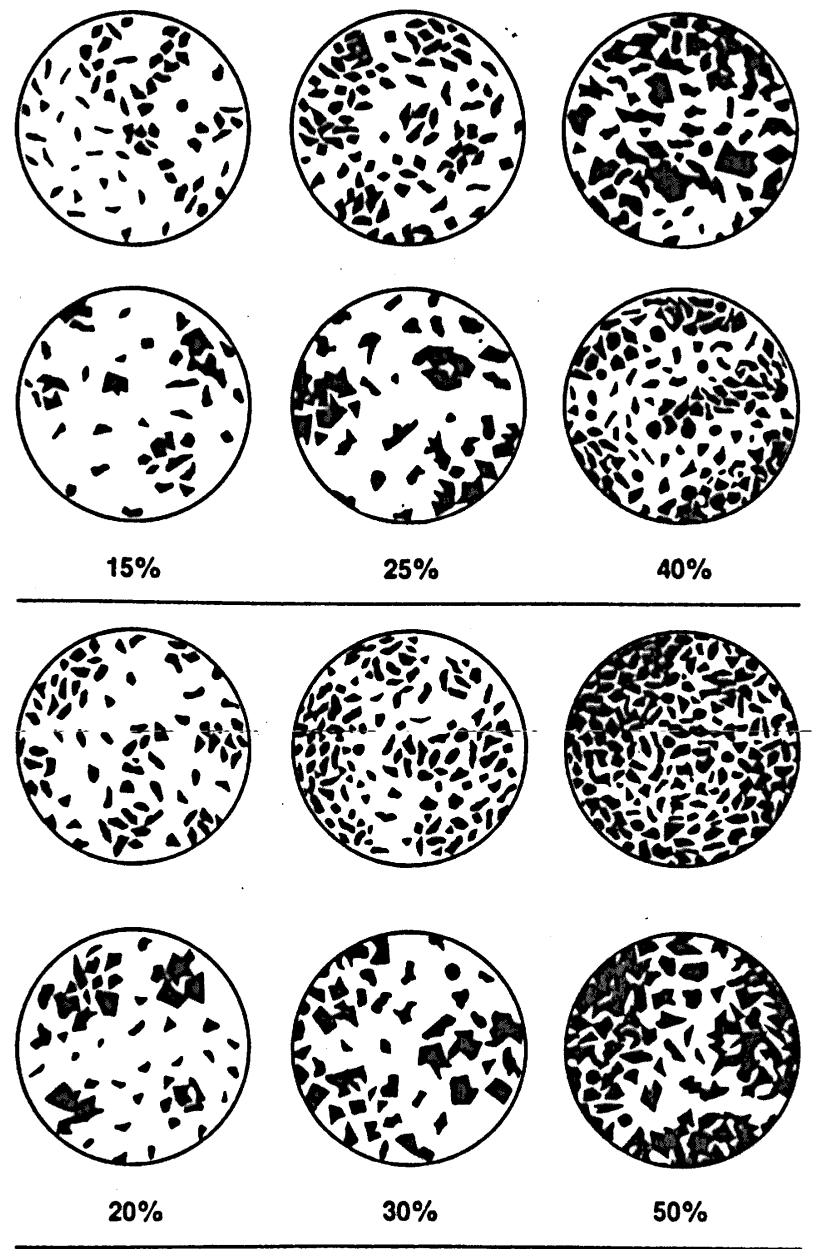

b. AGI data sheet 15.2

Figure 8. (Concluded) 


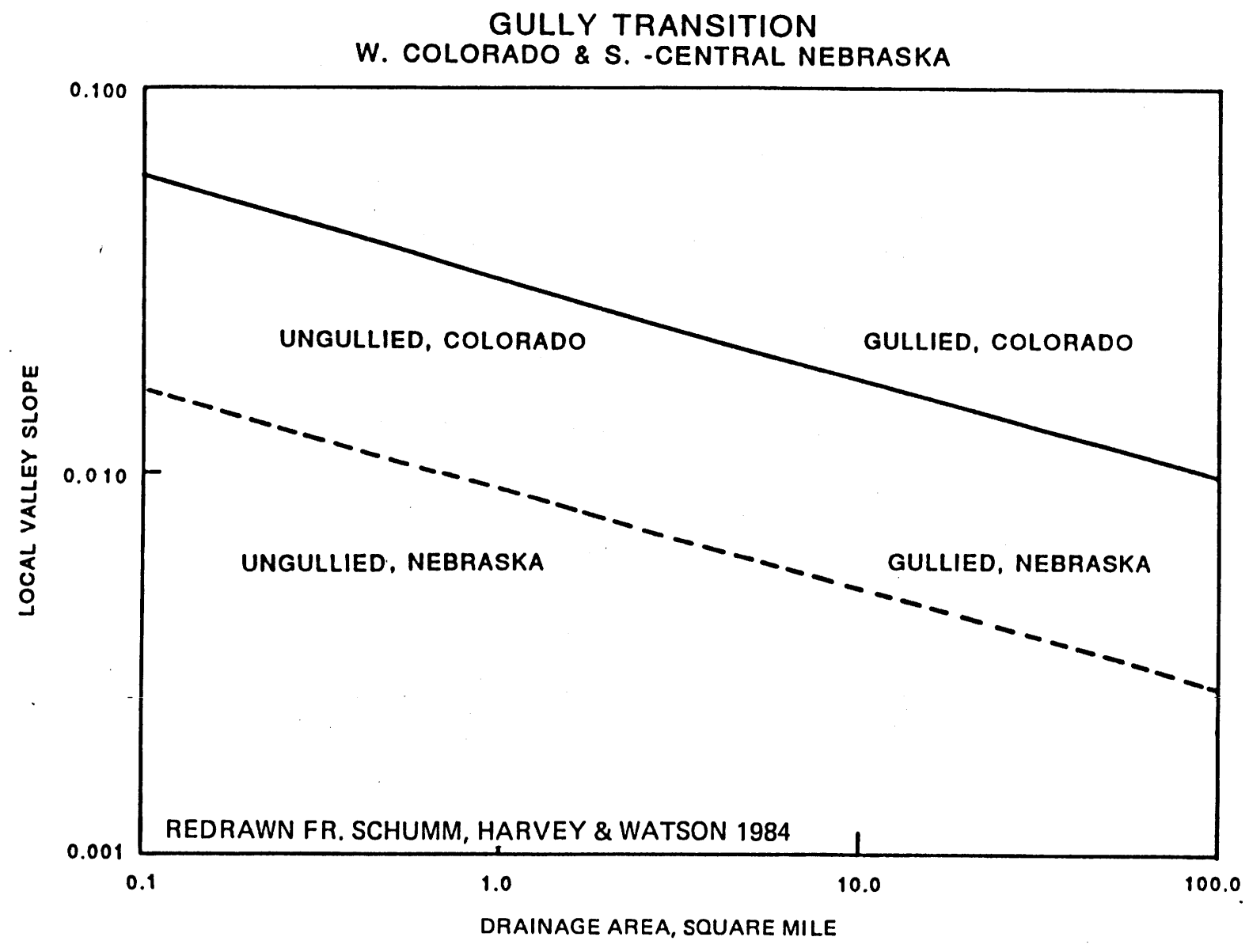

Figure 9. The gully transition threshold for western Colorado and southcentral Nebraska. The dashed line represents the threshold condition of valley slope versus drainage area (gullied above, ungullied below) for Nebraska; the solld line shows the same threshold for Colorado 